\title{
How glyphosate and its associated acidity affect early development in zebrafish (Danio rerio)
}

\author{
Mona Schweizer $^{\text {Corresp., } 1}$, Klaus Brilisauer ${ }^{2}$, Rita Triebskorn ${ }^{1,3}{ }^{,}$Karl Forchhammer $^{2}$, Heinz R Köhler ${ }^{1}$ \\ 1 Institute of Evolution and Ecology, Animal Physiological Ecology, Eberhard-Karls-Universität Tübingen, Tübingen, Germany \\ 2 Microbiology, Organismic Interactions, Eberhard-Karls-Universität Tübingen, Tübingen, Germany \\ 3 Steinbeis Transfer-Center for Ecotoxicology and Ecophysiology, Rottenburg am Neckar, Germany \\ Corresponding Author: Mona Schweizer \\ Email address: mona.schweizer@gmx.de
}

Background. Glyphosate is among the most extensively used pesticides worldwide. Following the ongoing highly controversial debate on this compound, its potential impact on non-target organisms is a fundamental scientific issue. In its pure compound form, glyphosate is known for its acidic properties.

Methods. We exposed zebrafish (Danio rerio) embryos to concentrations between $10 \mu \mathrm{M}$ and $10 \mathrm{mM}$ glyphosate in an unbuffered aqueous medium, as well as at pH 7, for 96 hours post fertilisation (hpf). Furthermore, we investigated the effects of aqueous media in the range of $\mathrm{pH} 3$ to $\mathrm{pH}$, in comparison with $1 \mathrm{mM}$ glyphosate treatment at the respective $\mathrm{pH}$ levels. Additionally, we exposed zebrafish to 7deoxy-sedoheptulose ( $7 \mathrm{dSh}$ ), another substance that interferes with the shikimate pathway by a mechanism analogous to that of glyphosate, at a concentration of $1 \mathrm{mM}$. The observed endpoints included mortality, the hatching rate, developmental delays at $24 \mathrm{hpf}$, the heart rate at $48 \mathrm{hpf}$ and the malformation rate at $96 \mathrm{hpf}$. $\mathrm{LC}_{10 / 50}, \mathrm{EC}_{10}$ and, if reasonable, $\mathrm{EC}_{50}$ values were determined for unbuffered glyphosate.

Results. The results revealed high mortalities in all treatments associated with low $\mathrm{pH}$, including high concentrations of unbuffered glyphosate $(>500 \mu \mathrm{M})$, low $\mathrm{pH}$ controls and glyphosate treatments with $\mathrm{pH}$ $<3.4$. Sublethal endpoints like developmental delays and malformations occurred mainly at higher concentrations of unbuffered glyphosate. In contrast, effects on the hatching rate became particularly prominent in treatments at $\mathrm{pH} 7$, showing that glyphosate significantly accelerates hatching compared with the control and 7dSh, even at the lowest tested concentration. Glyphosate also affected the heart rate, resulting in alterations both at $\mathrm{pH} 7$ and, even more pronounced, in the unbuffered system. In higher concentrations, glyphosate tended to accelerate the heart rate in zebrafish embryos, again, when not masked by the decelerating influence of its low $\mathrm{pH}$. At pH > 4, no mortality occurred, neither in the control nor in glyphosate treatments. At $1 \mathrm{mM}, 7 \mathrm{dSh}$ did not induce any mortality, developmental delays or malformations; only slightly accelerated hatching and a decelerated heart rate were observed. Our results demonstrate that lethal impacts in zebrafish embryos can be attributed mainly to low $\mathrm{pH}$, but we could also show a pH-independent effect of glyphosate on the development of zebrafish embryos on a sublethal level. 
1 How glyphosate and its associated acidity affect early development in zebrafish

3

4 Mona Schweizer ${ }^{1, *}$, Klaus Brilisauer ${ }^{2}$, Rita Triebskorn ${ }^{1,3}$, Karl Forchhammer ${ }^{2}$ and Heinz R Köhler ${ }^{1}$

5

6

7

8

9

10

*Corresponding author: Mona.Schweizer@gmx.de

11

12

13

14

15

16

17

18

19

20

21

22

23

24
(Danio rerio) 


\section{Abstract}

Background. Glyphosate is among the most extensively used pesticides worldwide. Following the ongoing highly controversial debate on this compound, its potential impact on non-target organisms is a fundamental scientific issue.

Methods. In its pure compound form, glyphosate is known for its acidic properties. We exposed zebrafish (Danio rerio) embryos to concentrations between $10 \mu \mathrm{M}$ and $10 \mathrm{mM}$ glyphosate in an unbuffered aqueous medium, as well as at $\mathrm{pH} \mathrm{7,} \mathrm{for} 96$ hours post fertilisation (hpf). Furthermore, we investigated the effects of aqueous media in the range of $\mathrm{pH} 3$ to $\mathrm{pH} 8$, in comparison with $1 \mathrm{mM}$ glyphosate treatment at the respective $\mathrm{pH}$ levels. Additionally, we exposed zebrafish to 7-deoxysedoheptulose (7dSh), another substance that interferes with the shikimate pathway by a mechanism analogous to that of glyphosate, at a concentration of $1 \mathrm{mM}$. The observed endpoints included mortality, the hatching rate, developmental delays at $24 \mathrm{hpf}$, the heart rate at $48 \mathrm{hpf}$ and the malformation rate at $96 \mathrm{hpf} . \mathrm{LC}_{10 / 50}, \mathrm{EC}_{10}$ and, if reasonable, $\mathrm{EC}_{50}$ values were determined for unbuffered 42 glyphosate.

Results. The results revealed high mortalities in all treatments associated with low $\mathrm{pH}$, including high concentrations of unbuffered glyphosate $(>500 \mu \mathrm{M})$, low pH controls and glyphosate treatments with $\mathrm{pH}<3.4$. Sublethal endpoints like developmental delays and malformations occurred mainly at higher concentrations of unbuffered glyphosate. In contrast, effects on the hatching rate became particularly prominent in treatments at $\mathrm{pH} 7$, showing that glyphosate significantly accelerates hatching compared with the control and 7dSh, even at the lowest tested concentration. Glyphosate also affected the heart 
rate, resulting in alterations both at $\mathrm{pH} 7$ and, even more pronounced, in the unbuffered system. In higher concentrations, glyphosate tended to accelerate the heart rate in zebrafish embryos, again, when not masked by the decelerating influence of its low $\mathrm{pH}$. At $\mathrm{pH}>4$, no mortality occurred, neither in the control nor in glyphosate treatments. At $1 \mathrm{mM}, 7 \mathrm{dSh}$ did not induce any mortality, developmental delays or malformations; only slightly accelerated hatching and a decelerated heart rate were observed. Our results demonstrate that lethal impacts in zebrafish embryos can be attributed mainly to low $\mathrm{pH}$, but we could also show a pH-independent effect of glyphosate on the development of zebrafish embryos on a sublethal level.

\section{Introduction}

Currently, glyphosate is the most extensively used herbicide worldwide (EC 2007, U.S. EPA 2011), and its approval for application within European Union borders was extended by the European Commission (EC 2017) for another five years in December 2017. Glyphosate was first used successfully in the 1970s as the active compound in the formulation Roundup ${ }^{\circledR}$ (Monsanto, St. Louis, USA) and is nowadays a component in numerous herbicides from various producers. In the U.S., glyphosate tops the list of applied agricultural herbicides and ranks second in home and garden applications (Battaglin et al. 2014). However, in the last couple of years, there have been very controversial debates concerning the effects of glyphosate-based herbicides on non-target organisms (e.g. Folmar, Sanders \& Julin 1979, Relyea 2005, Benamú, Schneider \& Sánchez 2010, Balbuena et al. 2015, Helmer et al. 2015, Motta, Raymann \& Moran 2018), whole ecosystems (e.g. Vera et al. 2010) and even on the health of human beings as the IARC rated glyphosate as probably carcinogenic in 2015 (IARC 2017). 
72 Glyphosate is a non-selective, broad-spectrum herbicide (Monsanto 2005) that inhibits aromatic acid

73 synthesis in plants by interfering with the shikimate pathway (Steinrücken \& Amrhein 1980, Bentley \&

74 Haslam 1990, Schönbrunn et al. 2001). Since the shikimate pathway is specific to plants, fungi, bacteria and some protists but is absent in animals, including humans (Maeda \& Dudareva 2012), glyphosate was regarded an ideal and safe application option. However, recent studies suggest the metabolisation of glyphosate by humans leading to adverse effects on human health, already caused by chronic low-dose glyphosate ingestion via residues in food and water (Swanson, Hoy \& Seneff 2016). Those potential effects include sub-clinical metabolic acidosis induced by shifts in the human gut microbiome, mitochondrial dysfunction, endocrine disruption, DNA damage and the inhibition of the cytochrome P450 enzyme system (Samsel \& Seneff 2013, Swanson et al. 2014, Swanson, Hoy \& Seneff 2016). Concerning application in the field, glyphosate is advertised as a herbicide with poor rainfastness (Baylis 2000), is known to bind to soil particles and is degraded by microbes (Rueppel et al. 1977, von WirénLehr et al. 1997, Forlani et al. 1999). Although Giesy, Dobson \& Solomon (2000) stated that less than $1 \%$ of glyphosate is washed from the leaves of plants by rainfall directly after application, spray drift and runoff may occur that contribute to the entry of glyphosate into non-target environments, particularly aquatic systems (Giesy, Dobson \& Solomon 2000). Furthermore, incidences of e.g. incorrect disposal of packages and expired herbicide remnants or careless cleansing of application instruments might enhance the amount of glyphosate entering the environment.

Since glyphosate is applied as formulation, additives like polyoxyethylene tallow amine (POEA), a surfactant that facilitates glyphosate uptake through the plant cuticula, are released into ecological systems inducing adverse effects on non-target organisms at least as severe as glyphosate itself (Perkins, Boermans \& Stephenson 2000, Tsui \& Chu 2003, Brausch, Beall \& Smith 2007, Bringolf et al. 2007, Moore et al. 2012, Defarge, Spiroux de Vendômois \& Séralini 2018). However, glyphosate is not 
96

97

98

99

100

101

102

103

104

105

106

107

108

109

110

111

112

113

114

115

116

117

118

119

fields (Struger et al. 2008), national parks (Battaglin et al. 2009) and urban areas (Botta et al. 2009) into surface waters and even groundwater. In the environment, glyphosate is degraded to $\mathrm{CO}_{2}$ and aminomethylphosphonic acid (AMPA), which, in turn, is degraded to inorganic phosphate, ammonium and $\mathrm{CO}_{2}$. Glyphosate's half-life depends on the surrounding matrix and is estimated between 4.2 and 14 days for fresh water (Giesy, Dobson \& Solomon 2000, Vera et al. 2010), mainly below 60 days in agricultural soils (Giesy, Dobson \& Solomon 2000, Grunewald et al. 2001) and between 47 and 315 days in seawater (Mercurio et al. 2014). Depending on time and location, Struger et al. (2008) measured a mean maximum glyphosate concentration in surface waters between 10 and $20 \mu \mathrm{g} / \mathrm{L}$, peaking at up to $40 \mu \mathrm{g} / \mathrm{L}$. Botta et al. (2009) could detect 75 to $90 \mu \mathrm{g} / \mathrm{L}$ in storm sewers after rainfall, and Battaglin et al. (2014) even found top concentrations up to $301 \mu \mathrm{g} / \mathrm{L}$ in lake/wetland samples. Although those findings range below the U.S. EPA's maximum contamination level of $700 \mu \mathrm{g} / \mathrm{L}$ (U.S. EPA 2009) or the Canadian long- and short-term freshwater aquatic life standards of 800 and $27000 \mu \mathrm{g} / \mathrm{L}$, respectively (Canadian Council of Ministers of the Environment 2012), adverse effects in non-target organisms in the environment have been demonstrated, as already indicated. Therefore, it is of major importance to further elucidate the mechanisms by which glyphosate affects non-target organisms and to assess its risk more realistically. In the long run, it could be conceivable to further establish ecologically sound alternatives, including bioherbicides and synthetic herbicides on the basis of natural phytotoxins (Dayan \& Duke 2014), that can potentially substitute for glyphosate.

Since this study is regarded as fundamental research, the zebrafish Danio rerio, as a prominent and easy-to-handle standard organism in the field of ecotoxicology, was used, and the glyphosate concentrations chosen were rather high $(1 \mu \mathrm{M}[1.69 \mathrm{mg} / \mathrm{L}]-10 \mathrm{mM}[1.69 \mathrm{~g} / \mathrm{L}])$ and less environmentally relevant, as glyphosate concentrations measured in surface waters lie mainly within a range of $\mu \mathrm{g} / \mathrm{L}$ (e.g. Struger et al. 2008, Botta et al. 2009, Battaglin et al. 2014). Glyphosate, in its pure compound form, is known to be a highly polar molecule, a polyprotic acid with $\mathrm{pK}_{\mathrm{a}}$ values of $<2,2.3$ and 5.6 (Bromilow et al. 
120 1993, Wade et al. 1993, Borggaard \& Gimsing 2008). Consequently, it lowers the pH of the medium

121 when in solution. As an ionisable substance, glyphosate exerts a higher toxicity in low pH environments, 122 where a higher proportion of the molecules are present in a neutral state, in which an uptake through 123 biomembranes is facilitated, compared to glyphosate ions (Erickson et al. 2006, Saparov, Antonenko \& 124 Pohl 2006, Ehrl et al. 2018). Thus, it might be expected that glyphosate toxicity is enhanced in systems 125 dealing with acidification already, whereas in systems characterised by more alkaline surroundings, the toxicity might be mitigated. Although glyphosate has been studied regarding its impact on non-target organisms, including adverse effects on early stages in zebrafish (e.g. Sulukan et al. 2017, Zhang et al. 2017, Fiorino et al. 2018), the influence of pH on toxicity results have not been considered so far.

The aim of our study was to differentiate the effects of glyphosate-induced acidification of the medium and those exerted by the compound itself (independent of low $\mathrm{pH}$ ) on embryonic and early larval development of Danio rerio. This study should provide lethal and effect concentration data $\left(\mathrm{LC}_{\mathrm{E}} \mathrm{EC}_{10}\right.$ and LC/EC $5_{50}$ ) for a more profound risk assessment. Besides mortality, additional sublethal endpoints, including hatching, the heart rate, developmental delays and malformations, were observed to account for subtler impacts on embryonic health. For that purpose, glyphosate was tested at concentrations between $10 \mu \mathrm{M}$ and $10 \mathrm{mM}$ in an unbuffered medium and in an aqueous medium adjusted to $\mathrm{pH}$ 7. In addition, the critical range of $\mathrm{pH}$ values was determined and tested with and without $1 \mathrm{mM}$ glyphosate.

137 To investigate whether possible effects are specific to glyphosate or to general inhibition of the shikimate pathway, we tested the newly described shikimate pathway inhibitor, 7-deoxy-sedoheptulose

139 (7dSh). This substance is produced by cyanobacteria and was used at a concentration of $1 \mathrm{mM}$, which is more than one order of magnitude above the effective concentration required to inhibit the shikimate pathway (Brilisauer et al. 2019). 


\section{Material and methods}

Glyphosate

147 Glyphosate [N-(phosphonomethyl)glycine, 96\% pure substance, molecular weight: $169.07 \mathrm{~g} / \mathrm{mol}$, CAS:

148 1071-83-6, Sigma-Aldrich, Merck KGaA, Darmstadt, Germany] was used to prepare the test solutions. A

149 stock solution with a concentration of $25 \mathrm{mM}$ was prepared as follows: glyphosate was diluted in 150 reconstituted water $\left(0.23 \mathrm{~g} \mathrm{KCl}, 2.59 \mathrm{~g} \mathrm{NaHCO}_{3}, 4.93 \mathrm{~g} \mathrm{MgS}_{4} \mathrm{O} \cdot 7 \mathrm{H}_{2} \mathrm{O}\right.$ and $11.76 \mathrm{~g} \mathrm{CaCl}_{2} \cdot 2 \mathrm{H}_{2} \mathrm{O}$ were 151 dissolved separately in $1 \mathrm{~L}$ double-distilled water, then $25 \mathrm{~mL}$ of each stock solution was added to 900 $152 \mathrm{~mL}$ double-distilled water). The stock solution was then diluted to the following test concentrations: 10 $153 \mu \mathrm{M}, 50 \mu \mathrm{M}, 100 \mu \mathrm{M}, 250 \mu \mathrm{M}, 500 \mu \mathrm{M}, 750 \mu \mathrm{M}, 1 \mathrm{mM}$ and $10 \mathrm{mM}$ glyphosate (respective specifications 154 for $\mathrm{mg} / \mathrm{L}$ and $\mathrm{pH}$ are given in Table 1). All those concentrations were tested unbuffered and at $\mathrm{pH}$ 7. For $155 \mathrm{pH}$ adjustments, $1 \mathrm{M} \mathrm{HCl}$ and $\mathrm{NaOH}$ solutions were used as recommended in the OECD 236 (2013) 156 guideline. For investigations of the influence of $\mathrm{pH}, 1 \mathrm{mM}$ glyphosate was tested at different $\mathrm{pH}$ values 157 ranging between $\mathrm{pH} 3$ and $\mathrm{pH} 8$ vs. the respective $\mathrm{pH}$ controls. Due to preliminary results from the 158 broad-scale $\mathrm{pH}$ testing, particular attention was paid to the range between $\mathrm{pH} 3$ and $\mathrm{pH} 4$. Measurements of $\mathrm{pH}$ were conducted with a pH meter (SevenCompactDuo, Mettler Toledo, Gießen, Germany) directly prior to the exposure.

7-deoxy-sedoheptulose (7-deoxy-D-altro-2-heptulose, 7dSh)

The compound 7-deoxy-sedoheptulose (7dSh) was obtained by chemoenzymatic synthesis and purified as described in Brilisauer et al. (2019). This 7dSh was tested at a $1 \mathrm{mM}$ concentration alongside the unbuffered glyphosate treatments in an unbuffered system. Thus, 7dSh was tested as a neutral solution, since it has no influence on $\mathrm{pH}$. 
169 The embryos used in this study stem from our own breeding stock of the Danio rerio [Hamilton 1822]

170 Westaquarium strain established in the Animal Physiological Ecology group, Tübingen University. Adult

171 zebrafish were kept in 90-L aquaria filled with a 1:1 mixture of purified water and filtered tap water (AE-

172 2L water filter with an ABL-0240-29 activated carbon filter, $0.3 \mu \mathrm{m}$; Reiser, Seligenstadt, Germany) at 26

$173 \pm 1{ }^{\circ} \mathrm{C}$ and an oxygen saturation of $100 \pm 5 \%$. Conductivity ranged from 260 to $350 \mu \mathrm{S} / \mathrm{cm}$, nitrite and

174 nitrate concentrations from 0.025 to $0.1 \mathrm{mg} / \mathrm{L}, 1$ and $5 \mathrm{mg} / \mathrm{L}$, respectively, and total water hardness

175 from 8 to $12{ }^{\circ} \mathrm{dH}$. Fish were subjected to an artificial 12:12 hour day/night cycle and fed three times

176 daily with flake food (TetraMin ${ }^{\circledR}$, Tetra $\mathrm{GmbH}$, Melle, Germany) supplemented with frozen black

177 mosquito larvae and glass worms (Poseidon Aquakultur Freeze, Ruppichteroth, Germany) prior to

178 spawning to ensure sufficient dietary protein.

179 The day before the test, pre-exposure and test Petri dishes (90 $\mathrm{mm}$ and $30 \mathrm{~mm}$ in diameter) were filled 180 with the respective solutions and stored at $26 \pm 1{ }^{\circ} \mathrm{C}$ overnight to saturate the glass (the same was done 181 with the Schott flask used for the stock solution, beforehand). On the morning of the test, Petri dishes 182 were emptied and refilled with $70 \mathrm{~mL}$ (pre-exposure) and $3 \mathrm{~mL}$ (test Petri dishes) solution. For spawning, 183 Plexiglas ${ }^{\circledR}$ boxes $20 \times 20 \times 6 \mathrm{~cm}$ in size and covered with a mesh grid to keep zebrafish from feeding on

their own eggs were used as breeding boxes. They were topped with artificial sea grass acting as an optical spawning stimulus and were placed into the fish tanks the evening before the start of the test. Zebrafish spawn at sunrise; therefore, spawning in the laboratory starts with the onset of light the next morning. Eggs were collected with a sieve, rinsed with tepid tap water, transferred into pre-exposure Petri dishes and incubated for 2 hours at $26 \pm 1{ }^{\circ} \mathrm{C}$. Following the pre-exposure, eggs for the test were chosen with regard to their age and developmental stage ( 0 hours post fertilisation [hpf] $\triangleq 8$ a.m.), placed into the small $30 \mathrm{~mm}$ Petri dishes and stored in a heated cabinet at $26 \pm 1^{\circ} \mathrm{C}$. A total of 32 individuals were used per treatment, i.e. four per Petri dish and eight replicates each. Embryos were 
192 checked every 12 to 24 hours. Endpoints investigated under a stereo microscope (Stemi 2000-C, Zeiss)

193 included mortality, developmental delays at $24 \mathrm{hpf}$, heart rate at $48 \mathrm{hpf}$, hatching success from 60 to 96

$194 \mathrm{hpf}$ and malformations at $96 \mathrm{hpf}$ (see Table 2). Except for mortality, analysis of all endpoints, including

195 hatching success, was based on living embryos/larvae at the respective time point of evaluation. Heart

196 rates were determined from two out of four individuals per Petri dish for 20 seconds, and values were

197 extrapolated to 1 minute. Coagulated eggs, dead larvae and empty egg shells were removed from the

198 Petri dishes to avoid depletion of oxygen due to biological degradation processes. The embryo test was

199 run three times and conducted according to OECD 236 (2013). The compound 3,4-dichloraniline (98\%,

200 CAS: 95-76-1, Sigma-Aldrich, Merck KGaA, Darmstadt, Germany) at a concentration of $4 \mathrm{mg} / \mathrm{L}$ served as

201 a positive control and reconstituted water, as a negative control.

202 According to the Directive 2010/63/EU of the European Parliament and the Council on the protection of 203 animals for scientific purposes, Danio rerio embryos and larvae that do not feed independently are not 204 regarded as animals, thus regulations and permissions for animal testing do not apply. Nevertheless, all

205

208

209

210

211

212 embryos in our tests were handled in the least stressful way possible and with the utmost care. After test termination embryos/larvae were euthanised with MS222.

\section{Statistics}

All statistical analyses were conducted in $J M P^{\circledR}$ 11.2.0 (SAS Institute Inc. 2013). Mortality, hatching success and the malformation rate at $96 \mathrm{hpf}$, as well as developmental delays at $24 \mathrm{hpf}$, were analysed with a likelihood-ratio $\chi^{2}$ test, followed by Fisher's exact test. Finally, the sequential Bonferroni-Holm method was applied accounting for multiple testing. A Cox regression was used to assess mortality and hatching success over time. For the analysis of heart rate, the data were averaged per Petri dish and checked for a normal distribution and homogeneity of variances. Subsequently an ANOVA with Tukey's HSD or Dunnett's test was conducted. If data did not meet the criteria for an ANOVA and transformation 
216 of the data did not lead to the desired result, a non-parametric Steel-Dwass test was conducted instead.

217 Additionally, for assessing the $\mathrm{pH}$ range in which $\mathrm{pH}$ control and glyphosate treatments differed in heart

218 rate across the whole span of tested $\mathrm{pH}$, non-linear regression analysis, including calculation of $95 \%$

219 confidence intervals (TableCurve 2D v5.01, SYSTAT Software Inc. 1989-2001), was applied. Non-linear

220 regression analysis by TableCurve was also used for determining $\mathrm{LC}_{10} / \mathrm{EC}_{10}$ and $\mathrm{LC}_{50} / \mathrm{EC}_{50}$ values of 221 endpoints in unbuffered glyphosate treatments.

222

223

224

\section{Results}

225

226

After 96 hpf, mortality and hatching success were $0 \%$ and above $80 \%$, respectively, in control embryos.

The 3,4-dichloraniline positive control induced high mortalities, with rates consistently above $80 \%$ after

96 hpf. Thus, the validity criteria according to OECD 236 (2013), including sensitivity of zebrafish, were met.

Unbuffered glyphosate

232

233

234

235

236

At the two highest concentrations tested (1 and $10 \mathrm{mM}$ ), it was already difficult to select well-developed eggs after the two hours pre-exposure period. The yolk sac, which usually has a regular spherical shape, was found to be asymmetric and partly oval, and the chorion fluid, which is naturally clear, was murky in some cases and contained indefinable streaks (Fig. 1). As early as $12 \mathrm{hpf}$, all individuals, without exception, in the $10 \mathrm{mM}$ treatment died (Fig. 2A). Mortality in the $1 \mathrm{mM}$ exposure experiment was beyond $85 \%$ at $12 \mathrm{hpf}$ and reached $100 \%$ within the first 24 hours. Within the $750 \mu \mathrm{M}$ glyphosate treatment, only 6 out of a total of 96 individuals survived until the end of the test at $96 \mathrm{hpf}$, whereas concentrations of $250 \mu \mathrm{M}$ and below resulted in negligible or no mortality ( $\leq 3.125 \%)$. Regarding 
240 mortality at $96 \mathrm{hpf}$, all treatments $\geq 500 \mu \mathrm{M}$ were highly significantly different from the control

241 (likelihood ratio $\chi^{2}, \mathrm{p}<0.001$ ). Lethal concentrations were calculated to be $385 \mu \mathrm{M}\left(\mathrm{LC}_{10}\right)$ and $582 \mu \mathrm{M}$

$242\left(\mathrm{LC}_{50}\right)$ at $96 \mathrm{hpf}$.

243 Heart rates showed a concentration-dependent relationship, decreasing with increasing glyphosate

244 concentration (Fig. 2B). The mean heart rate was 149 beats per minute [bpm] for the control and 245 between 130 and $140 \mathrm{bpm}$ for low $(10 \mu \mathrm{M}, 50 \mu \mathrm{M}), 120$ and $130 \mathrm{bpm}$ for medium (100 $\mu \mathrm{M}, 250 \mu \mathrm{M})$

246 and 110 and $120 \mathrm{bpm}$ for the higher $(500 \mu \mathrm{M}, 750 \mu \mathrm{M})$ concentrations. Thus, differences between the

247 control and the $750 \mu \mathrm{M}$ concentration ranged between 30 and 40 beats per minute. The treatments

248 with the highest concentrations of glyphosate $(1 \mathrm{mM}, 10 \mathrm{mM})$ could not be evaluated due to $100 \%$

249 mortality at that time point. Only two individuals out of those exposed to $1 \mathrm{mM}$ glyphosate survived

250 until $60 \mathrm{hpf}$ and seemed to continue the observed relationship between glyphosate and heart rate by

251 showing even lower rates (93 and $96 \mathrm{bpm}$ ). As single individuals, they were not included in the statistical

252 analysis. All remaining treatments were significantly different from the control (ANOVA with Tukey's

$253 \mathrm{HSD}, \mathrm{p}<0.001)$ and the relationship between glyphosate concentration and heart rate could be

254 described by linear regression analysis $\left(R^{2}=0.546074, p<0.001\right)$. The $\mathrm{EC}_{10}$ was $43 \mu \mathrm{M}$.

255 Concerning the hatching rate, we observed a clear division between a cluster of treatments that

256 comprised the control treatment and lower concentrations of glyphosate $(10 \mu \mathrm{M}, 50 \mu \mathrm{M}, 100 \mu \mathrm{M})$ and

257 another treatment cluster comprising higher concentrations $(250 \mu \mathrm{M}, 500 \mu \mathrm{M}, 750 \mu \mathrm{M})$ (Fig. 2C).

258 Embryos exposed to lower concentrations hatched in 98 to $100 \%$ of cases, whereas hatching success in

259 the experiments with 250 and $500 \mu \mathrm{M}$ glyphosate was approximately $40 \%$. All glyphosate treatments

260 showed significant differences compared with the control (Cox regression, $\mathrm{p}<0.05$ ). $\mathrm{EC}_{10}$ and $\mathrm{EC}_{50}$ levels

261 at $96 \mathrm{hpf}$ were 155 and $224 \mu \mathrm{M}$, respectively.

262 There were no developmental delays at $24 \mathrm{hpf}$ for glyphosate concentrations between 10 and $100 \mu \mathrm{M}$,

263 whereas in treatments with 250 to $750 \mu \mathrm{M}$, rates varied from $15 \%$ to $25 \%$ (data summarised in Table

Peer) reviewing PDF | (2019:02:35284:1:1:NEW 2 May 2019) 
264 3). The $\mathrm{EC}_{10}$ for this endpoint was $126 \mu \mathrm{M}$. Results for all concentrations $\geq 250 \mu \mathrm{M}$ were highly

265 significant (likelihood ratio $\chi^{2}, p<0.001$ ) compared with the control. A direct concentration dependency

266 could not be observed. Rather, it seemed that a distinct concentration threshold had to be exceeded to

267 induce those developmental delays and failures, which later approached the same level. Prevalent

268 defects were a lack of tail detachment, sometimes combined with apically curved tails (Fig. 3F); a lack of

269 somite formation and an impairment of eye development was not detected. Occasionally, embryos

270 were fully developed but either the complete tail or just the posterior end of their tails remained

271 attached to the yolk sac (Fig. 3E). Under normal conditions, movement begins after tail detachment. Yet,

272 even the embryos in glyphosate treatments that lacked tail detachment, overall development had

273 progressed to a point at which muscular contractions were already visible. But due to the undetached

274 tails, embryos were unable to turn around and their movement was very limited. Additionally, some

275 embryos had the posterior end of their tails detached but displayed severe spine deformations (Fig. 3G,

$276 H, I)$. Those embryos could not move their tails in the same fluid manner as normally developed embryos

277 could.

278 Malformations could be found in embryos of all glyphosate treatments but with rates below $20 \%$ (data

279 summarised in Table 3). All glyphosate treatments were significantly different from the control. Among

280 the malformations recorded, lightly pigmented embryos and larvae were particularly frequent (Fig. 4C).

281 Furthermore, reduced eye size occurred regularly (Fig. 4B), and some individuals suffered from cardiac

282 or yolk sac oedemas (Fig. 4E). Two individuals showed a notable shortening of the tail (Fig. 4D).

283 Deformations of the spine at $96 \mathrm{hpf}$ were observed surprisingly rarely, despite the high rates of tail and

284 spine malformations at $24 \mathrm{hpf}$.

285 In contrast to the glyphosate results, unbuffered $7 \mathrm{dSh}$, thus at a neutral $\mathrm{pH}$, did not induce mortality

286 throughout any of the experiments, and no developmental delays or malformations occurred in $7 \mathrm{dSh}-$

287 exposed embryos. Sublethal effects were limited to a slightly decelerated heart rate (140 bpm), which 
corresponded to the $10 \mu \mathrm{M}$ glyphosate treatment (138 bpm) but was $8 \mathrm{bpm}$ lower than in embryos of the negative control (ANOVA with Dunnett's test, $p<0.001$ ), and an accelerated hatching over time (Cox regression, $p<0.05)$ compared with the negative control. At $60 \mathrm{hpf}$, the hatching rates in the $7 \mathrm{dSh}-$ exposed group and the negative control were similar but clearly below those of the groups exposed to low glyphosate concentrations. At $72 \mathrm{hpf}, 7 \mathrm{dSh}$ outpaced the negative control and converged on the results of 10 to $100 \mu \mathrm{M}$ glyphosate treatments. In contrast, the hatching success of $7 \mathrm{~d}$ Sh-exposed embryos at $96 \mathrm{hpf}$ did not differ from that of the negative control.

\section{Glyphosate at $\mathrm{pH} 7$}

When the glyphosate solutions were adjusted to $\mathrm{pH} 7$, almost no mortality or developmental delays occurred, and malformation rates were below $10 \%$ but were still significantly elevated in $1 \mathrm{mM}$ and 10 $\mathrm{mM}$ treatments (likelihood ratio $\chi^{2}, \mathrm{p}<0.001$; Table 3). In the concentration range of 10 to $500 \mu \mathrm{M}$, heart rates showed a similar trend to those in unbuffered treatments but at a lower level: beats per minute decreased with increasing concentration (Fig. 2B). Still, treatments between 100 and $500 \mu \mathrm{M}$ differed significantly from the negative control (Tukey's HSD, $\mathrm{p}<0.01$ ). At $750 \mu \mathrm{M}$, heart rates increased again, with a higher frequency than at 250 and $500 \mu \mathrm{M}$. At the two highest concentrations ( $1 \mathrm{mM}, 10$ $\mathrm{mM})$, heart rates were, on the one hand, marginally decelerated $(1 \mathrm{mM})$ and on the other hand, marginally accelerated $(10 \mathrm{mM})$ compared with the negative control. Thus, it seems that there is a turning point between 500 and $750 \mu \mathrm{M}$, at which the relationship between increasing concentration and heart rate shifts from deceleration to acceleration in comparison with the negative control.

As already seen for lower concentrations in unbuffered treatments, glyphosate tends to induce early hatching, even at the lowest concentration and independently of concentration. This effect unfolded to its true extent in the $\mathrm{pH}$-neutral treatments (Fig. 2D). At least twice as much larvae had hatched across

311 all glyphosate treatments at $60 \mathrm{hpf}$ compared with the negative control. After $72 \mathrm{hpf}$, all larvae were 
312 hatched in glyphosate treatments, except for single individuals that hatched at $96 \mathrm{hpf}$ or did not hatch at

313 all, whereas in the negative control, only $53 \%$ of the embryos were hatched at $72 \mathrm{hpf}$ and even about

$31415 \%$ remained unhatched at $96 \mathrm{hpf}$.

315

316

pH range

317 In a first step, 1 mM glyphosate was tested at $\mathrm{pH} 3, \mathrm{pH} 4, \mathrm{pH} \mathrm{5,} \mathrm{pH} \mathrm{6,} \mathrm{pH} 7$ and $\mathrm{pH} 8$ in comparison with negative controls at the respective $\mathrm{pH}$ but without the pesticide (Fig. 5). Mortality was $100 \%$ for both treatments at $\mathrm{pH} 3$, independent of the presence of glyphosate. Only a single individual survived the first $12 \mathrm{hpf}$. In contrast, only one individual died throughout all other exposures within $96 \mathrm{hpf}$. Morphological aberrations described for high glyphosate concentrations under unbuffered conditions (Fig. 1 and 3) also applied to low $\mathrm{pH}$ treatments, independent of glyphosate addition. Concerning sublethal endpoints, results between different acidities in the range of $\mathrm{pH} 4$ to $\mathrm{pH} 8$, as well as between control and glyphosate within the same $\mathrm{pH}$ range, were inconspicuous for the most part. Thus, the $\mathrm{pH} 3$ to $\mathrm{pH} 8$ series was tested just once, and subsequent testing concentrated on the range from $\mathrm{pH} 3$ to $\mathrm{pH} 4$. Thus, in the next step, $\mathrm{pH} 3, \mathrm{pH} 3.25, \mathrm{pH} 3.5, \mathrm{pH} 3.75$ and $\mathrm{pH} 4$ were investigated in detail. As embryos exposed to $\mathrm{pH} 3.75$ and $\mathrm{pH} 4$ did not show any prominent effects, only a single run was conducted, and the final testing scheme was determined from $\mathrm{pH} 3$ to $\mathrm{pH} 3.5$ in 0.1 increments. Additionally, a test with unbuffered glyphosate at a $1 \mathrm{mM}$ concentration (which resulted in a $\mathrm{pH}$ of 3.2 in the test solution) was included for direct comparison.

Mortality decreased with increasing pH. Treatments with a pH of 3.2 and lower induced $100 \%$ mortality after $96 \mathrm{hpf}$. Whereas embryos exposed to $\mathrm{pH} 3$ and pH 3.1 died within $48 \mathrm{hpf}$ at the latest, embryos in pH 3.2 treatments survived considerably longer (Fig. 5). Apart from pH 3.5 without glyphosate, all treatments showed elevated mortality rates compared with the negative control (Cox regression, 335 $\mathrm{p}<0.05)$. There were no differences between control and glyphosate treatments with corresponding $\mathrm{pH}$ 
336

337 control.

338 Compared with the negative control, hatching was significantly delayed and also reduced in both

values, except for the elevated mortality in unbuffered glyphosate compared with the respective pH 3.2 glyphosate and $\mathrm{pH}$ control treatments (Cox regression, $\mathrm{p}<0.001$ ). Whereas $30 \%$ of the control embryos hatched at $60 \mathrm{hpf}$, in the $\mathrm{pH}$ control and glyphosate exposures, the hatching rate at $60 \mathrm{hpf}$ was consistently below $5 \%$ (see supplementary file, hatching rate). The tendency toward glyphosateinduced premature hatching at $60 \mathrm{hpf}$ that was observed in $\mathrm{pH}$-neutral treatments was not evident at low $\mathrm{pH}$. Although not statistically significant (except for $\mathrm{pH} 3.5$ : Cox regression, $\mathrm{p}<0.001$ ), embryos exposed to glyphosate tended to hatch earlier and more frequently than embryos in the respective $\mathrm{pH}$ controls (see also Table 3).

Heart rates were significantly lowered by glyphosate at $\mathrm{pH} 3.3$ to 3.5 , as well as by the corresponding control pH treatments (Steel-Dwass, $\mathrm{p}<0.001$ ). Differences between glyphosate and the respective controls at the same $\mathrm{pH}$ value could only be detected when the full $\mathrm{pH}$ range dataset (including results for $\mathrm{pH} 3$ to $\mathrm{pH}$ 8) was analysed. At a $\mathrm{pH}$ between 5.55 and 6.02, glyphosate elevated the embryonic heart rate significantly compared with $\mathrm{pH}$ controls (TableCurve 2D v5.01; Fig. 6). Developmental delays and malformations occurred in the low $\mathrm{pH}$ treatments, but they did not vary in a $\mathrm{pH}$-dependent manner, and there was no detectable difference between glyphosate and the respective $\mathrm{pH}$ controls.

\section{Comparison}

When datasets for the unbuffered glyphosate treatment and the $\mathrm{pH}$ range were merged regarding mortality in relation to $\mathrm{pH}$ (Fig. 5), interestingly, embryos exposed to unbuffered glyphosate showed higher mortalities at 500 and $750 \mu \mathrm{M}$ compared with their $1 \mathrm{mM}$ counterparts at $\mathrm{pH} 3.5$ and pH 3.4 , respectively. The unbuffered $750 \mu \mathrm{M}$ treatment with a pH of 3.4, in particular, resulted in a mortality 
359 rate more than twice as high as that in the glyphosate $\mathrm{pH} 3.4$ treatment $(1 \mathrm{mM})$, mirroring mortality

360 effects seen in treatments ranging rather between $\mathrm{pH} 3.25$ and $\mathrm{pH} 3.3$.

361

362

363

Discussion

364

365

The results we obtained for unbuffered glyphosate treatments are in close agreement with those reported in the literature. Fiorino et al. (2018) found mortality rates below $10 \%$ for concentrations between 0.005 and $10 \mathrm{mg} / \mathrm{L}(<100 \mu \mathrm{M}$, compare to Table 1$)$, as well as $17 \%$ mortality in $50 \mathrm{mg} / \mathrm{L}(\approx 295$ $\mu \mathrm{M})$ treatments after 96 hpf. Uren Webster et al. (2014) and Stehr et al. (2009) found no effect on mortality in embryos exposed to concentrations up to $10 \mathrm{mg} / \mathrm{L}$ after $96 \mathrm{hpf}$. Those findings are in line with our results for unbuffered glyphosate treatments. By contrast, Bortagary et al. (2010) also tested higher glyphosate concentrations and detected mortalities of $35.4 \%$ ( $25 \mathrm{mg} / \mathrm{L}), 74 \%$ (75 mg/L) and $82 \%$ (150 mg/L) as early as $24 \mathrm{hpf}$. Their rates were remarkably higher than ours, in particular concerning concentrations of 25 and $75 \mathrm{mg} / \mathrm{L}$; however, the exposure temperature in Bortagary's set-up was $27.9^{\circ} \mathrm{C}$ and thus about $2 \mathrm{~K}$ higher than in our experiments. Although zebrafish easily tolerate temperatures around $28{ }^{\circ} \mathrm{C}$ (López-Olmeda \& Sánchez-Vázquez 2011), a $2 \mathrm{~K}$ temperature difference may result in a higher metabolic rate. Thus, the effects of substances set in faster and might be more severe. Nevertheless, the abundance and characteristics of developmental delays and malformations from Bortagary's experiment matched our findings. They described delays in separation of the yolk sac that very likely coincide with the lack of tail detachment observed in this study. Additionally, they found deformations of the spine and deformities in the tail area that are in line with the findings presented here. Similar effects occurred in glyphosate tests with Java medaka (Oryzias javanicus) embryos. Yusof, 
383 from 100 to $500 \mathrm{mg} / \mathrm{L}$ glyphosate. Morphological alterations described for zebrafish embryos included

384 yolk sac and pericardial oedema, deformations of the skeleton and spine and misshapen yolk sacs

385 (Bortagary et al. 2010, Sulukan et al. 2017, Fiorino et al. 2018) and thus corresponded, at least partly, to

386 our findings of oedema, light pigmentation and small eyes. In Java medaka, embryo malformations like

387 disproportional head and body sizes, bends in tails and a lack of cornea were found (Yusof, Ismail \& Alias

388 2014). Similar findings were reported in Xenopus laevis embryos incubated with 1/5000 dilutions of

389 glyphosate-based herbicides. Those embryos showed alterations in cephalic and neural crest

development and a shortening of the anterior-posterior axis, and when glyphosate was injected, optic

vesicles were reduced, resulting in the formation of smaller eyes or in their complete reduction. In chick

embryos, such an effect could be attributed to an increase in the activity of endogenous retinoic acid

(Paganelli et al. 2010). Retinoic acid is a derivative of vitamin A that is crucial to various processes in

vertebrates and thus ensures the proper development of zebrafish embryos on numerous levels (Holder

\& Hill 1991, Marsh-Armstrong et al. 1994, Stafford \& Prince 2002, Kawakami et al. 2005, Keegan et al.

2005, Laue et al. 2008). As a consequence, interference in retinoic acid signalling has the potential to

cause developmental delays and malformations during embryonic development in vertebrates. In this

context, Sulukan et al. (2017) investigated potential correlations of malformation induction with

carbonic anhydrases (CA), an enzyme family that is involved in various biological processes, including

respiration, $\mathrm{CO}_{2}$ and ion transport, acid-base balance and the formation of reactive oxygen species

401

(ROS). They found malformations in all treatments $(1-100 \mathrm{mg} / \mathrm{L})$, with simultaneous inhibition of CA and 
407 Although our results for mortality, developmental delays and malformations are in line with findings

408 reported in literature, which did not consider glyphosate-induced pH decrease, they were not 409 reproduced by glyphosate at $\mathrm{pH}$ 7. In a comprehensive analysis of data from $\mathrm{pH}$ control and glyphosate 410 treatments, it can be seen that the described effects occurred independently of glyphosate or its 411 concentration, as long as an acid milieu below pH 3.75 was provided. In the case of those endpoints in 412 zebrafish embryos, sublethal effects may be detected only between $\mathrm{pH} 3.3$ and $\mathrm{pH} 3.75$. A pH lower 413 than 3.25 induced $100 \%$ mortality within $96 \mathrm{hpf}$ and within $12 \mathrm{hpf}$ at pH 3, whereas pH 3.75 to $\mathrm{pH} 8$ did 414 not affect survival. However, it is not unlikely that sublethal effects caused by glyphosate itself are 415 masked by the severe consequences of low $\mathrm{pH}$.

416 Even though our data revealed that the effects detected here and also reported in the literature are 417 likely to be caused mainly by low $\mathrm{pH}$ values, our data indicate that even at neutral $\mathrm{pH}$, glyphosate affects 418 embryonic development. Early hatching reported, for example, by Uren Webster et al. (2014) and 419 Bortagary et al. (2010) at concentrations between 10 and $50 \mathrm{mg} / \mathrm{L}$ could be observed in pH neutral treatments in particular and was not concentration dependent. As all embryos seemed to be well 421 developed at the point of hatching, early hatching should be interpreted as accelerated chorion 422 degradation rather than as premature hatching. According to Kimmel et al. (1995), the hatching period of Danio rerio starts as early as at $48 \mathrm{hpf}$ already, and there is no developmental difference under 424 normal conditions between larvae that hatch spontaneously and those remaining in the chorion. Thus, 425 glyphosate at $\mathrm{pH} 7$ seems to contribute to more spontaneous hatching instances. During embryo 426 handling throughout the test, it was striking that the chorion of individuals within low $\mathrm{pH}$ and/or 427 glyphosate treatments was more sensitive to physical contact, e.g. while positioning embryos, compared 428 with negative control embryos. Chorions were never injured during the test procedure but became 429 dented easily. Through movements within eggs, embryos bulged out the dents by themselves rapidly. 430 Hence, accelerated hatching might be correlated with a more damageable chorion that has ruptured 
431 sooner as a result of movements of the embryo with or without direct hatching intention. The fact that

432 the effect of accelerated hatching was found to be more pronounced in $\mathrm{pH} 7$ treatments might be due

433 to the developmental status. Developmentally retarded embryos with late detachment of the tail in

434 lower $\mathrm{pH}$ treatments were less agile than normally developed individuals in neutral treatments at the

435 same time point and thus were less likely to rupture the chorion accidently. This assumption is basically

436 supported by observations from Yusof, Ismail \& Alias (2014), who found a thinning of the embryonic

437 chorion of Java medaka following a 100 to $500 \mathrm{mg} / \mathrm{L}$ glyphosate exposure, and Zhang et al. (2017), who

438 detected a decrease in surface tension of the chorion combined with an increase in locomotion that

439 might lead to accelerated hatching in zebrafish embryos.

440 Regarding the heart rate, concentration dependency was still apparent at neutral $\mathrm{pH}$, although it was

441 less pronounced than in the unbuffered glyphosate treatments. At a high glyphosate concentration, the

442 decreasing effect on the heart rate seemed to reverse, as the heart accelerated again. The outcomes of

443 the $\mathrm{pH}$ range treatments corroborate the importance of $\mathrm{pH}$ to the heart rate but also the potential of

444 glyphosate at $1 \mathrm{mM}$ to accelerate the heart rate considerably, at least between pH 5.55 and pH 6.05.

445 Few studies have evaluated the effect of glyphosate on the heart rate in zebrafish embryos. Bortagary et

446 al. (2010) reported a decrease in the heart rate following exposure to concentrations exceeding 25

$447 \mathrm{mg} / \mathrm{L}$, whereas Roy et al. (2016) studied the effect of glyphosate on the cardiovascular system in detail

448 but solely regarding a single concentration. Their finding of a heart rate of $129 \mathrm{bpm}$ in response to 50

$449 \mathrm{mg} / \mathrm{L}$ glyphosate matches our results of $130 \mathrm{bpm}$ at a slightly lower concentration of $250 \mu \mathrm{M}$ glyphosate

450 at neutral $\mathrm{pH}$ (compare Table 1), whereas it differed from the unbuffered treatment with a delta of

451 about 4. Differences between studies might be attributed to temperature impact. Zebrafish embryos in

452 this study were reared and observed at $26^{\circ} \mathrm{C}$, whereas Roy et al. (2016) conducted the entire test at

$45328.5^{\circ} \mathrm{C}$. The specific effect of temperature on the zebrafish heart rate has been addressed previously

454 (Schweizer et al. 2017). The observed progressive decrease in heart rate might be correlated to 
455

456

457

structural abnormalities found by Roy et al. (2016) for the impact of glyphosate on heart development. In that study, the shape and size of the atrium and ventricle changed and decreased, the endocardium was thickened and the vascular network throughout the body was poorly connected. As a result, erythrocytes could not move properly and were slowed down on their way through the organism, contributing to the formation of cardiac oedema. Although there are no references for the effects of higher glyphosate concentrations on the zebrafish heart rate, our results are in agreement with a study on Java medaka embryos by Yusof, Ismail \& Alias (2014). The authors used 100 to $500 \mathrm{mg} / \mathrm{L}$ glyphosate and detected only acceleration of the heart rate. A glyphosate concentration of $100 \mathrm{mg} / \mathrm{L}$ corresponds to a glyphosate concentration of $591.47 \mu \mathrm{M}$ and thus relates approximately to the turning point between 500 and $750 \mu \mathrm{M}$, at which the decreasing trend in the heart rate was reversed.

Our study supports previous findings of negative effects of glyphosate on fish embryonic stages but, for the first time, distinguishes between direct consequences of the substance itself (hatching, heart rate) and indirect effects by lowering the $\mathrm{pH}$ of the surrounding medium (mortality, developmental delays, malformations). Since the primary target of glyphosate is absent in metazoans, the toxic side-effects of glyphosate may be caused either by secondary target sites or indirectly by inhibition of the shikimate pathway in the associated microbiome of the tested animals (Samsel \& Seneff 2013, Motta, Raymann \& Moran 2018) or impairment of symbiotic microorganisms in engineered plants with the glyphosateinsensitive EPSP synthase class II (Zobiole et al. 2010), respectively. Since the control compound 7dSh, which also inhibits the shikimate pathway, did not cause the side-effects observed for glyphosate, the observed effects were more likely caused by secondary target sites of glyphosate.

Although the tested concentrations were rather high compared with measured field concentrations, the inherent adverse potential of glyphosate in combination with further increasing application rates is worrying. Lethal and severe sublethal effects might be prominently driven by glyphosate's ability to 
drastically lower pH but, given that its acidic character contributes largely to its efficacy, the herbicide's

480 action and the $\mathrm{pH}$ can hardly be considered separately. Due to their acidity, glyphosate anions have a

481 high affinity to bind to cations and build neutral salt complexes, which enhance uptake through

482 biomembranes (Rendal, Kusk \& Trapp 2011). Nevertheless, their high binding capacities also apply to

483 strongly charged cations in soil (e.g. $\mathrm{Fe}^{3+} \mathrm{Al}^{3+}$ ), whose binding inactivates glyphosate (Borggaard \&

484 Gimsing 2008, Helander, Saloniemi \& Saikkonen 2012), which, in turn, seems to make leaching into

485 surface water or groundwater - per se - a minor problem. However, glyphosate competes with

486 phosphate for binding sites (Borggaard \& Gimsing 2008). In phosphate-saturated soils that prevail in

487 areas of intensive agriculture, in which glyphosate is preferably applied, soil particles have a very limited

488 capacity to bind glyphosate anions in addition to phosphate (Helander, Saloniemi \& Saikkonen 2012).

489 Consequently, in these cases, leaching of glyphosate into waters must be taken into account. If

490 glyphosate is leached into surface waters with little buffering capacity, side effects of the pesticide

491 should not be underestimated (e.g. Folmar, Sanders \& Julin 1979, Howe et al. 2004, Relyea 2005,

492 Paganelli et al. 2010, Vera et al. 2010, Lopes et al. 2014, Uren Webster et al. 2014, Roy et al. 2016,

493 Fiorino et al. 2018). In particular, when glyphosate comes in contact with organisms under slightly acidic

494 conditions: Ehrl et al. (2018) showed that the permeability of glyphosate through biomembranes is

495 increased in a slightly acidic compared to a neutral surrounding. Thus, it may be assumed that

496 glyphosate effects increase with lower $\mathrm{pH}$ based on a facilitated uptake of glyphosate into cells.

497 Although recent studies even suggest, that the toxicity exerted by glyphosate in the field is rather

498 caused by certain additives within applied formulations, including POEA, than by glyphosate itself (Tsui

499 \& Chu 2003, Moore et al. 2012, Defarge, Spiroux de Vendômois \& Séralini 2018), we could clearly show

500 that glyphosate as pure compound is able to induce adverse effects in a non-target organism. And in the

501 light of potential health effects even in human beings induced by a chronic but low dose exposure to

502 glyphosate (Samsel \& Seneff 2013, Swanson et al. 2014, Swanson, Hoy \& Seneff 2016), the ideal 
503 prospective solution for this issue would be a long-term replacement of glyphosate. The compound

$5047 d S h$, which bases its efficacy on interfering with the shikimate pathway, similar to glyphosate, seems to

505 be a promising candidate. Its effectiveness in plants has been demonstrated (Brilisauer et al. 2019), and

506 in contrast to glyphosate, it neither lowers $\mathrm{pH}$ nor induces severe effects in zebrafish embryos, as shown

507 in our study. No mortality, developmental delays or malformations could be detected in embryos 508 exposed to $1 \mathrm{mM} 7 \mathrm{dSh}$.

509

510

511 Conclusions

512

513 Although the severe effects detected seemed to be mainly caused by a low (glyphosate induced) $\mathrm{pH}$, the

514 compound glyphosate itself affects embryonic development in Danio rerio on a sublethal level. Direct

515 comparison between $\mathrm{pH}$ controls and $1 \mathrm{mM}$ glyphosate at the respective $\mathrm{pH}$ showed only minor

516 differences, but severe pH effects might mask the impacts of glyphosate. From a non-target perspective,

517 it would be advantageous to buffer glyphosate to a neutral level to avoid the severest effects on fish if

518 glyphosate were leached into the aquatic environment at higher concentrations. As glyphosate's acidity

519 elevates its efficacy as a herbicide, such a recommendation is highly unlikely to be implemented by 520 producers and users. In view of the protection of non-target species from side effects, alternatives

521 should be considered that might potentially substitute glyphosate in the long term, and we have shown

522 that 7dSh may be a promising emerging candidate.

523

524

525 Acknowledgements

526 We thank Prof. S. Grond for providing facilities for the preparation of 7dSh. 
References

530

531

532

533

534

535

536

537

538

539

540

541

542

543

544

545

546

547

548

549

550

551

552

553

554

555

556

557

558

559

560

561

562

563

564

565

566

567

568

569

570

Balbuena, M. S., Tison, L., Hahn, M.-L., Greggers, U., Menzel, R. and Farina, W. M. (2015). "Effects of sublethal doses of glyphosate on honeybee navigation." The Journal of Experimental Biology 218(17): 2799-2805.

Battaglin, W. A., Meyer, M. T., Kuivila, K. M. and Dietze, J. E. (2014). "Glyphosate and its degradation product AMPA occur frequently and widely in U.S. soils, surface water, groundwater, and precipitation." Journal of the American Water Resources Association 50(2): 275-290.

Battaglin, W. A., Rice, K. C., Focazio, M. J., Salmons, S. and Barry, R. X. (2009). "The occurrence of glyphosate, atrazine, and other pesticides in vernal pools and adjacent streams in Washington, DC, Maryland, lowa, and Wyoming, 2005-2006." Environmental Monitoring and Assessment 155(1): 281-307.

Baylis, A. D. (2000). "Why glyphosate is a global herbicide: strengths, weaknesses and prospects." Pest Management Science 56(4): 299-308.

Benamú, M. A., Schneider, M. I. and Sánchez, N. E. (2010). "Effects of the herbicide glyphosate on biological attributes of Alpaida veniliae (Araneae, Araneidae), in laboratory." Chemosphere 78(7): 871-876.

Bentley, R. and Haslam, E. (1990). "The shikimate pathway - a metabolic tree with many branches." Critical reviews in biochemistry and molecular biology 25(5): 307-384.

Borggaard, O. K. and Gimsing, A. L. (2008). "Fate of glyphosate in soil and the possibility of leaching to ground and surface waters: a review." Pest Management Science 64(4): 441-456.

Bortagary, V., Aramburu, R., Barrios, L., Ojeda, P., Puerto, G. and Rodríguez-Ithurralde, D. (2010). "Embryotoxicity and teratogenesis in zebrafish embryos exposed in vitro to glyphosate-type herbicides." Journal of Developmental Toxicology.

Botta, F., Lavison, G., Couturier, G., Alliot, F., Moreau-Guigon, E., Fauchon, N., Guery, B., Chevreuil, M. and Blanchoud, H. (2009). "Transfer of glyphosate and its degradate AMPA to surface waters through urban sewerage systems." Chemosphere 77(1): 133-139.

Brausch, J. M., Beall, B. and Smith, P. N. (2007). "Acute and sub-lethal toxicity of three POEA surfactant formulations to Daphnia magna." Bulletin of environmental contamination and toxicology 78(6): 510-514.

Brilisauer, K., Rapp, J., Rath, P., Schöllhorn, A., Bleul, L., Weiß, E., Stahl, M., Grond, S. and Forchhammer, K. (2019). "Cyanobacterial antimetabolite 7-deoxy-sedoheptulose blocks the shikimate pathway to inhibit the growth of prototrophic organisms." Nature Communications 10(1): 545.

Bringolf, R. B., Cope, W. G., Mosher, S., Barnhart, M. C. and Shea, D. (2007). "Acute and chronic toxicity of glyphosate compounds to glochidia and juveniles of Lampsilis siliquoidea (unionidae)." Environmental Toxicology and Chemistry 26(10): 2094-2100.

Bromilow, R. H., Chamberlain, K., Tench, A. J. and Williams, R. H. (1993). "Phloem translocation of strong acids - glyphosate, substituted phosphonic and sulfonic acids - in Ricinus communis L." Pesticide Science 37(1): 39-47.

Canadian Council of Ministers of the Environment (2012). "Scientific criteria document for the development of the Canadian water quality guidelines for the protection of aquatic life: Glyphosate." National Guidelines and Standards Office, Winnipeg, Canada, Winnipeg, Canada.

Peer) reviewing PDF | (2019:02:35284:1:1:NEW 2 May 2019) 
571

Dayan, F. E. and Duke, S. O. (2014). "Natural compounds as next-generation herbicides." Plant Physiology 166(3): 1090-1105.

Defarge, N., Spiroux de Vendômois, J. and Séralini, G. E. (2018). "Toxicity of formulants and heavy metals in glyphosate-based herbicides and other pesticides." Toxicology Reports 5: 156-163.

Ehrl, B. N., Mogusu, E. O., Kim, K., Hofstetter, H., Pedersen, J. A. and Elsner, M. (2018). "High permeation rates in liposome systems explainrapid glyphosate biodegradation associated with strong isotope fractionation." Environmental Science \& Technology 52(13): 7259-7268.

Erickson, R. J., McKim, J. M., Lien, G. J., Hoffman, A. D. and Batterman, S. L. (2006). "Uptake and elimination of ionizable organic chemicals at fish gills: I. Model formulation, parameterization, and behavior." Environmental Toxicology and Chemistry 25(6): 1512-1521.

Fiorino, E., Sehonova, P., Plhalova, L., Blahova, J., Svobodova, Z. and Faggio, C. (2018). "Effects of glyphosate on early life stages: comparison between Cyprinus carpio and Danio rerio." Environmental Science and Pollution Research 25(9): 8542-8549.

Folmar, L. C., Sanders, H. O. and Julin, A. M. (1979). "Toxicity of the herbicide glyphosate and several of its formulations to fish and aquatic invertebrates." Archives of Environmental Contamination and Toxicology 8(3): 269-278.

Forlani, G., Mangiagalli, A., Nielsen, E. and Suardi, C. M. (1999). "Degradation of the phosphonate herbicide glyphosate in soil: evidence for a possible involvement of unculturable microorganisms." Soil Biology and Biochemistry 31(7): 991-997.

Giesy, J. P., Dobson, S. and Solomon, K. R. (2000). "Ecotoxicological risk assessment for Roundup ${ }^{\circledR}$ herbicide." Reviews of environmental contamination and toxicology, Springer: 35-120.

Grunewald, K., Schmidt, W., Unger, C. and Hanschmann, G. (2001). "Behavior of glyphosate and aminomethylphosphonic acid (AMPA) in soils and water of reservoir Radeburg II catchment (Saxony/Germany)." Journal of Plant Nutrition and Soil Science 164(1): 65-70.

Helander, M., Saloniemi, I. and Saikkonen, K. (2012). "Glyphosate in northern ecosystems." Trends in Plant Science 17(10): 569-574.

Helmer, S. H., Kerbaol, A., Aras, P., Jumarie, C. and Boily, M. (2015). "Effects of realistic doses of atrazine, metolachlor, and glyphosate on lipid peroxidation and diet-derived antioxidants in caged honey bees (Apis mellifera)." Environmental Science and Pollution Research 22(11): 8010-8021.

Holder, N. and Hill, J. (1991). "Retinoic acid modifies development of the midbrain-hindbrain border and affects cranial ganglion formation in zebrafish embryos." Development 113(4): 1159-1170.

Howe, C. M., Berrill, M., Pauli, B. D., Helbing, C. C., Werry, K. and Veldhoen, N. (2004). "Toxicity of glyphosate-based pesticides to four North American frog species." Environmental Toxicology and Chemistry 23(8): 1928-1938.

IARC - International Agency for Research on Cancer (2017). "Some organophosphate insecticides and herbicides." IARC Monographs on the Evaluation of Carcinogenic Risks to Humans, Lyon, France: 112.

Kawakami, Y., Raya, Á., Raya, R. M., Rodríguez-Esteban, C. and Belmonte, J. C. I. (2005). "Retinoic acid signalling links left-right asymmetric patterning and bilaterally symmetric somitogenesis in the zebrafish embryo." Nature 435: 165.

Keegan, B. R., Feldman, J. L., Begemann, G., Ingham, P. W. and Yelon, D. (2005). "Retinoic acid signaling restricts the cardiac progenitor pool." Science 307(5707): 247-249.

Kimmel, C. B., Ballard, W. W., Kimmel, S. R., Ullmann, B. and Schilling, T. F. (1995). "Stages of embryonic development of the zebrafish." Developmental Dynamics 203(3): 253-310.

Laue, K., Jänicke, M., Plaster, N., Sonntag, C. and Hammerschmidt, M. (2008). "Restriction of retinoic acid activity by Cyp26b1 is required for proper timing and patterning of osteogenesis during zebrafish development." Development 135(22): 3775-3787. 
618

619

620

621

622

623

624

625

626

627

628

629

630

631

632

633

634

635

636

637

638

639

640

641

642

643

644

645

646

647

648

649

650

651

652

653

654

655

656

657

658

659

660

661

662

663

664

665

Lopes, F. M., Varela Junior, A. S., Corcini, C. D., da Silva, A. C., Guazzelli, V. G., Tavares, G. and da Rosa, C. E. (2014). "Effect of glyphosate on the sperm quality of zebrafish Danio rerio." Aquatic Toxicology 155: 322-326.

López-Olmeda, J. F. and Sánchez-Vázquez, F. J. (2011). "Thermal biology of zebrafish (Danio rerio)." Journal of Thermal Biology 36(2): 91-104.

Maeda, H. and Dudareva, N. (2012). "The shikimate pathway and aromatic amino acid biosynthesis in plants." Annual Review of Plant Biology 63(1): 73-105.

Marsh-Armstrong, N., McCaffery, P., Gilbert, W., Dowling, J. E. and Dräger, U. C. (1994). "Retinoic acid is necessary for development of the ventral retina in zebrafish." Proceedings of the National Academy of Sciences 91(15): 7286-7290.

Mercurio, P., Flores, F., Mueller, J. F., Carter, S. and Negri, A. P. (2014). "Glyphosate persistence in seawater." Marine Pollution Bulletin 85(2): 385-390.

Monsanto (2005). "Backgrounder - History of Monsanto's Glyphosate Herbicides." https://monsanto.com/app/uploads/2017/06/back history.pdf (accessed 08.02.2018).

Moore, L. J., Fuentes, L., Rodgers, J. H., Bowerman, W. W., Yarrow, G. K., Chao, W. Y. and Bridges, W. C. (2012). "Relative toxicity of the components of the original formulation of Roundup to five North American anurans." Ecotoxicology and Environmental Safety 78: 128-133.

Motta, E. V. S., Raymann, K. and Moran, N. A. (2018). "Glyphosate perturbs the gut microbiota of honey bees." Proceedings of the National Academy of Sciences 115(41): 10305-10310.

OECD (2013). "Test No. 236: Fish Embryo Acute Toxicity (FET) Test." OECD Publishing, Paris.

Paganelli, A., Gnazzo, V., Acosta, H., López, S. L. and Carrasco, A. E. (2010). "Glyphosate-based herbicides produce teratogenic effects on vertebrates by impairing retinoic acid signaling." Chemical Research in Toxicology 23(10): 1586-1595.

Perkins, P. J., Boermans, H. J. and Stephenson, G. R. (2000). "Toxicity of glyphosate and triclopyr using the frog embryo teratogenesis assay - Xenopus." Environmental Toxicology and Chemistry 19(4): 940-945.

Relyea, R. A. (2005). "The lethal impact of Roundup on aquatic and terrestrial amphibians." Ecological Applications 15(4): 1118-1124.

Rendal, C., Kusk, K. O. and Trapp, S. (2011). "Optimal choice of $\mathrm{pH}$ for toxicity and bioaccumulation studies of ionizing organic chemicals." Environmental Toxicology and Chemistry 30(11): 23952406.

Roy, N. M., Ochs, J., Zambrzycka, E. and Anderson, A. (2016). "Glyphosate induces cardiovascular toxicity in Danio rerio." Environmental Toxicology and Pharmacology 46: 292-300.

Rueppel, M. L., Brightwell, B. B., Schaefer, J. and Marvel, J. T. (1977). "Metabolism and degradation of glyphosate in soil and water." Journal of Agricultural and Food Chemistry 25(3): 517-528.

Samsel, A. and Seneff, S. (2013). "Glyphosate's suppression of cytochrome P450 enzymes and amino acid biosynthesis by the gut microbiome: pathways to modern diseases." Entropy 15(4): 1416.

Saparov, S. M., Antonenko, Y. N. and Pohl, P. (2006). "A new model of weak acid permeation through membranes revisited: Does Overton still rule?" Biophysical Journal 90(11): L86-L88.

Schönbrunn, E., Eschenburg, S., Shuttleworth, W. A., Schloss, J. V., Amrhein, N., Evans, J. N. S. and Kabsch, W. (2001). "Interaction of the herbicide glyphosate with its target enzyme 5enolpyruvylshikimate 3-phosphate synthase in atomic detail." Proceedings of the National Academy of Sciences 98(4): 1376-1380.

Schweizer, M., Dieterich, A., Triebskorn, R. and Köhler, H.-R. (2017). "Drifting away of a FET endpoint: The heart rate in Danio rerio embryos is extremely sensitive to variation in ambient temperature." Bulletin of Environmental Contamination and Toxicology.

Stafford, D. and Prince, V. E. (2002). "Retinoic acid signaling is required for a critical early step in zebrafish pancreatic development." Current Biology 12(14): 1215-1220.

Peer] reviewing PDF | (2019:02:35284:1:1:NEW 2 May 2019) 
666

667

668

669

670

671

672

673

674

675

676

677

678

679

680

681

682

683

684

685

686

687

688

689

690

691

692

693

694

695

696

697

698

699

700

701

702

703

704

705

706

707

708

709

710

Stehr, C. M., Linbo, T. L., Baldwin, D. H., Scholz, N. L. and Incardona, J. P. (2009). "Evaluating the effects of forestry herbicides on fish development using rapid phenotypic screens." North American Journal of Fisheries Management 29(4): 975-984.

Steinrücken, H. C. and Amrhein, N. (1980). "The herbicide glyphosate is a potent inhibitor of 5enolpyruvylshikimic acid-3-phosphate synthase." Biochemical and Biophysical Research Communications 94(4): 1207-1212.

Struger, J., Thompson, D., Staznik, B., Martin, P., McDaniel, T. and Marvin, C. (2008). "Occurrence of glyphosate in surface waters of Southern Ontario." Bulletin of Environmental Contamination and Toxicology 80(4): 378-384.

Sulukan, E., Köktürk, M., Ceylan, H., Beydemir, Ş., Işik, M., Atamanalp, M. and Ceyhun, S. B. (2017). "An approach to clarify the effect mechanism of glyphosate on body malformations during embryonic development of zebrafish (Danio rerio)." Chemosphere 180: 77-85.

Swanson, N. L., Hoy, J. and Seneff, S. (2016). "Evience that glyphosate is a causative agent in chronic subclinical metabolic acidosis and mitochondrial dysfunction." International Journal of Human Nutrition and Functional Medicine 4: 32-52.

Swanson, N. L., Leu, A., Abrahamson, J. and Wallet, B. (2014). "Genetically engineered crops, glyphosate and the deterioration of health in the United States of America." Journal of Organic Systems 9(2): 6-37.

Tsui, M. T. K. and Chu, L. M. (2003). "Aquatic toxicity of glyphosate-based formulations: comparison between different organisms and the effects of environmental factors." Chemosphere 52(7): 1189-1197.

Uren Webster, T. M., Laing, L. V., Florance, H. and Santos, E. M. (2014). "Effects of glyphosate and its formulation, Roundup, on reproduction in zebrafish (Danio rerio)." Environmental Science \& Technology 48(2): 1271-1279.

U.S. EPA (2009). "National primary drinking water regulations." U.S. Environmental Protection Agency, Washington, DC.

Vera, M. S., Lagomarsino, L., Sylvester, M., Pérez, G. L., Rodríguez, P., Mugni, H., Sinistro, R., Ferraro, M., Bonetto, C., Zagarese, H. and Pizarro, H. (2010). "New evidences of Roundup ${ }^{\circledR}$ (glyphosate formulation) impact on the periphyton community and the water quality of freshwater ecosystems." Ecotoxicology 19(4): 710-721.

von Wirén-Lehr, S., Komoßa, D., Gläßgen, W. E., Sandermann Jr, H. and Scheunert, I. (1997). "Mineralization of $\left[{ }^{14} \mathrm{C}\right]$ glyphosate and its plant-associated residues in arable soils originating from different farming systems." Pesticide Science 51(4): 436-442.

Wade, B. R., Riechers, D. E., Liebla, R. A. and Wax, L. M. (1993). "The plasma membrane as a barrier to herbicide penetration and site for adjuvant action." Pesticide Science 37(2): 195-202.

Yusof, S., Ismail, A. and Alias, M. S. (2014). "Effect of glyphosate-based herbicide on early life stages of Java medaka (Oryzias javanicus): A potential tropical test fish." Marine Pollution Bulletin 85(2): 494-498.

Zhang, S., Xu, J., Kuang, X., Li, S., Li, X., Chen, D., Zhao, X. and Feng, X. (2017). "Biological impacts of glyphosate on morphology, embryo biomechanics and larval behavior in zebrafish (Danio rerio)." Chemosphere 181: 270-280.

Zobiole, L. H. S., Oliveira, R. S., Kremer, R. J., Constantin, J., Yamada, T., Castro, C., Oliveira, F. A. and Oliveira, A. (2010). "Effect of glyphosate on symbiotic $\mathrm{N}_{2}$ fixation and nickel concentration in glyphosate-resistant soybeans." Applied Soil Ecology 44(2): 176-180.

Peer) reviewing PDF | (2019:02:35284:1:1:NEW 2 May 2019) 
Figure 1

Figure 1: Danio rerio embryos at $3.3 \mathrm{hpf}$ ("high stage", blastula period, according to Kimmel et al. (1995)).

A) Control embryo; B), C), D) exemplary embryos with irregularly growing cellular "hood" or misshapen yolk sacs from $1 \mathrm{mM}$ glyphosate concentration; as seen at five times magnification under a stereo microscope (Stemi 2000-C, Zeiss). 


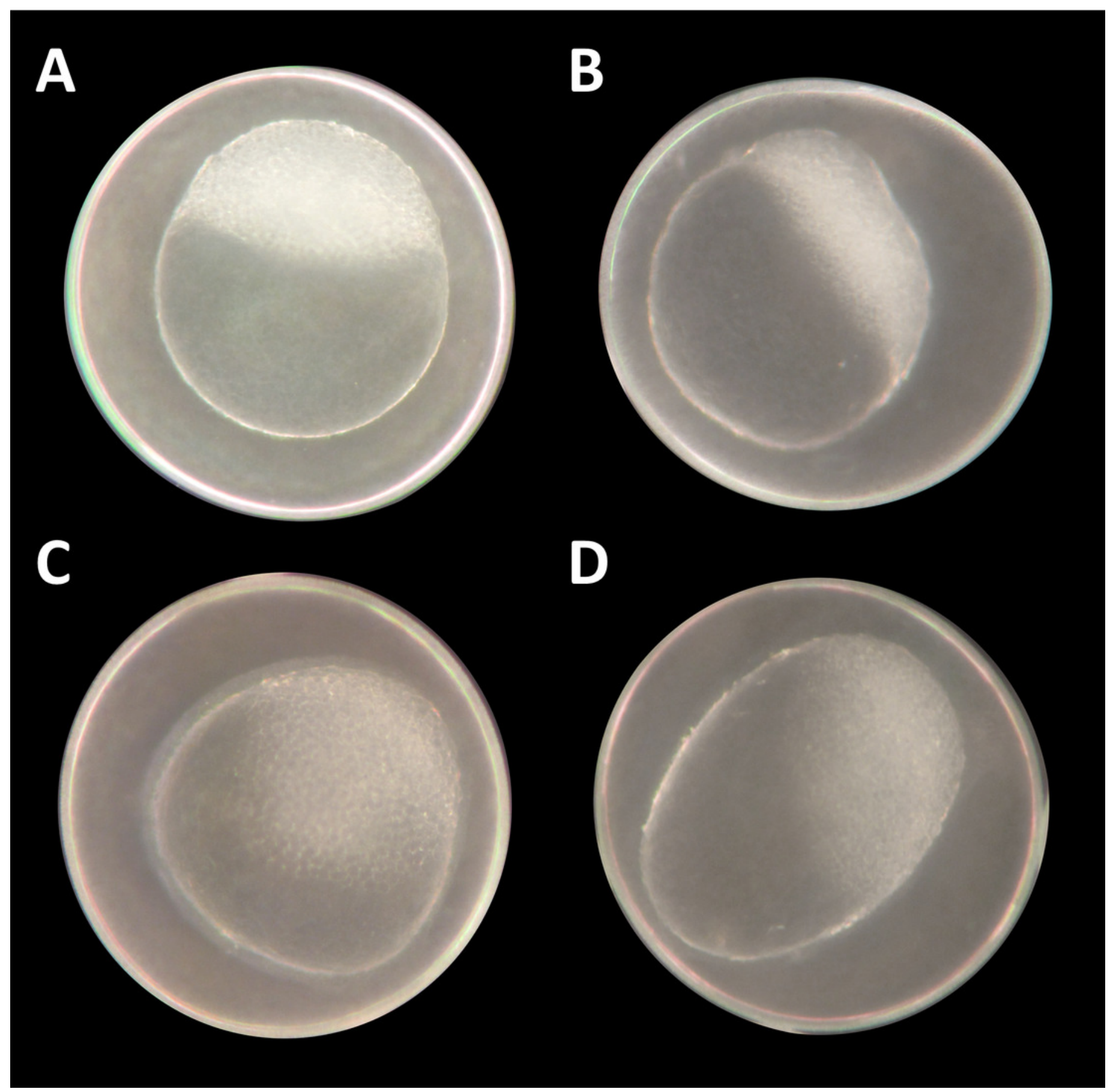


Figure 2

Figure 2: Mortality, heart rate and hatching success in percentage of unbuffered and $\mathrm{pH}$ 7 treatment.

A) Mortality after $96 \mathrm{hpf}$ (likelihood ratio $\chi^{2}$, Fisher's exact test, Bonferroni-Holm, $p<\alpha$ ), B) heart rate at $48 \mathrm{hpf}$ relative to the negative control (Steel-Dwass, $p<0.01$ ), C) hatching rate over time in unbuffered treatments (Cox regression, $\mathrm{p}<0.05$ ), D) hatching rate in $\mathrm{pH} 7$ treatments over time (Cox regression, $p<0.001$ ); shaded bars mark treatments with $n<5$ that show tendencies but are not included in the statistical analyses.

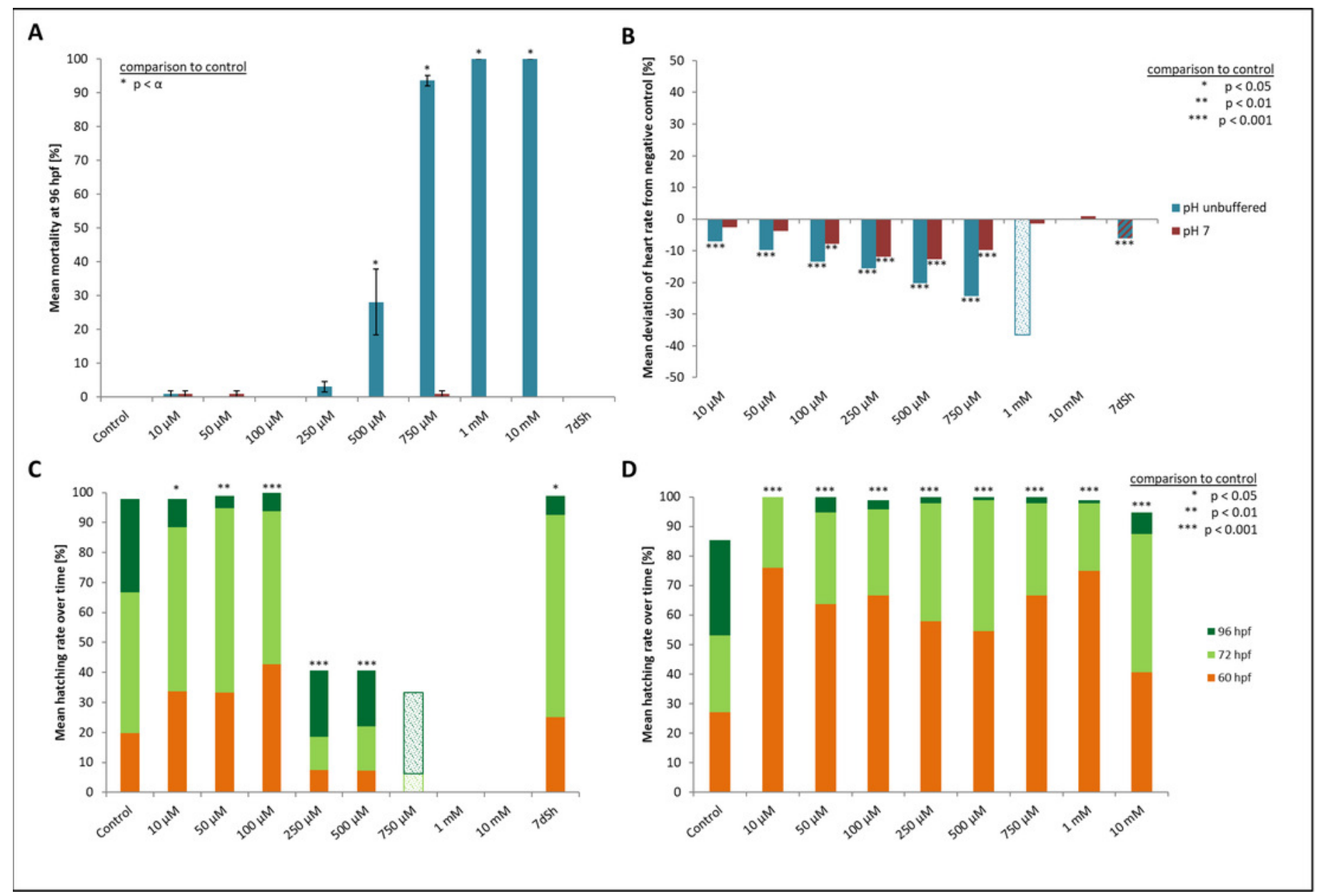




\section{Figure 3}

Figure 3: Danio rerio embryos at $24 \mathrm{hpf}$.

A) Coagulated control embryo; B) coagulated embryo in glyphosate (1 mM); C) streaks within the chorion; D) control embryo; E) no detachment of the tail; F) attached tail growing curved at the distal end; G) dorsal dent; H) irregular curved spine; I) anomalously straight tail; as seen at five times magnification under a stereo microscope (Stemi 2000-C, Zeiss).

*Note: Auto Gamma Correction was used for the image. This only affects the reviewing manuscript. See original source image if needed for review. 


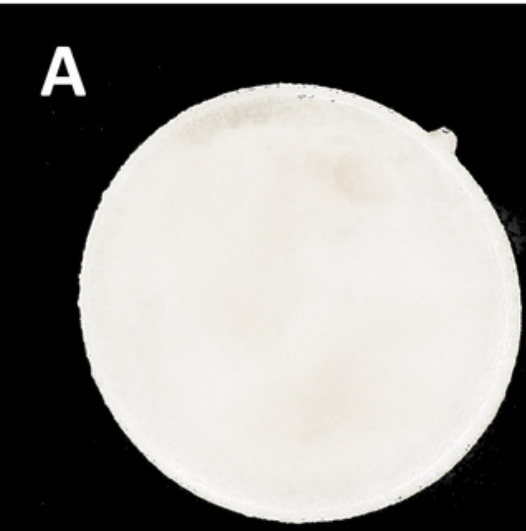

B

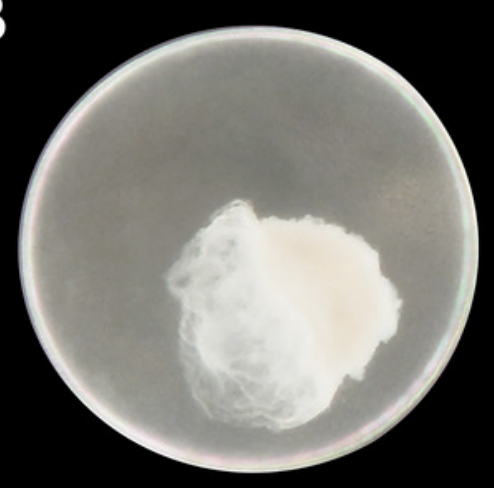

D

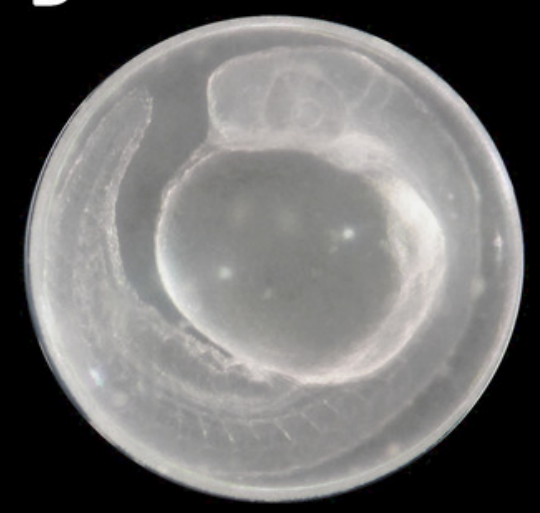

G

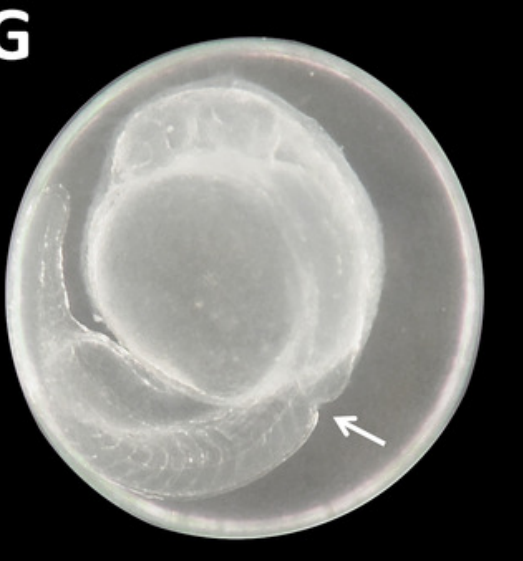

E

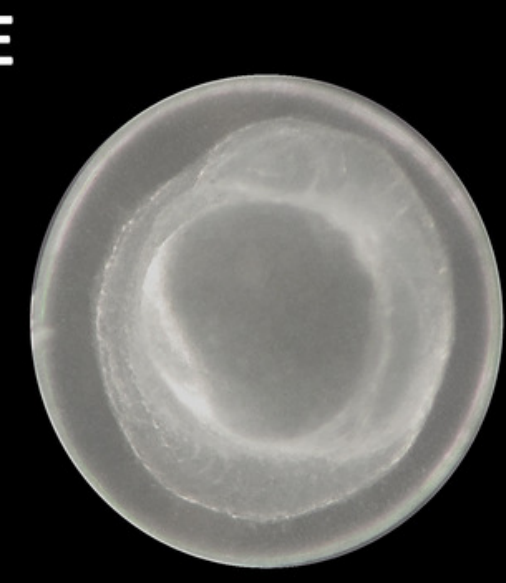

H

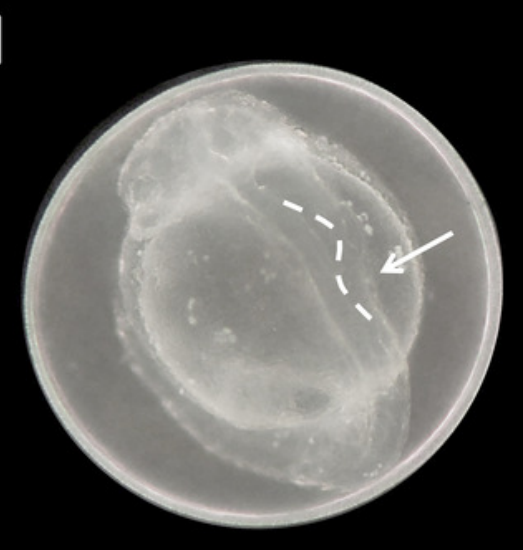

C

$\mathbf{F}$

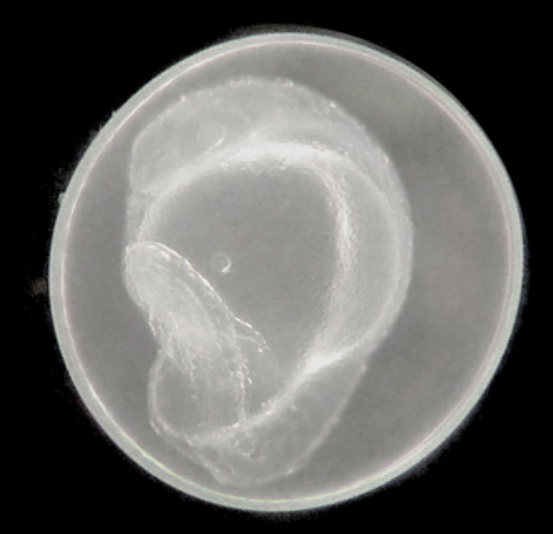

I

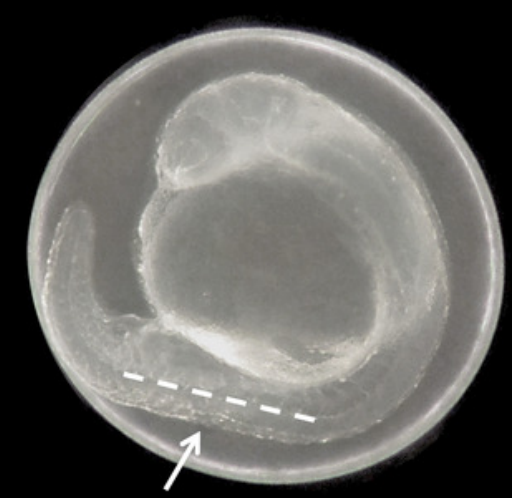




\section{Figure 4}

Figure 4: Danio rerio larvae at $96 \mathrm{hpf}$.

A) Control; B) upper larvae with smaller eyes compared with control individual below; C) right larvae with light pigmentation compared with control individual on the left; D) larvae with a shortened tail; E) larvae with cardiac oedema; F) larvae with spine deformation; D)-F) larvae show smaller eyes as regular, additionally; as seen at three to five times magnification under a stereo microscope (Stemi 2000-C, Zeiss).

*Note: Auto Gamma Correction was used for the image. This only affects the reviewing manuscript. See original source image if needed for review.

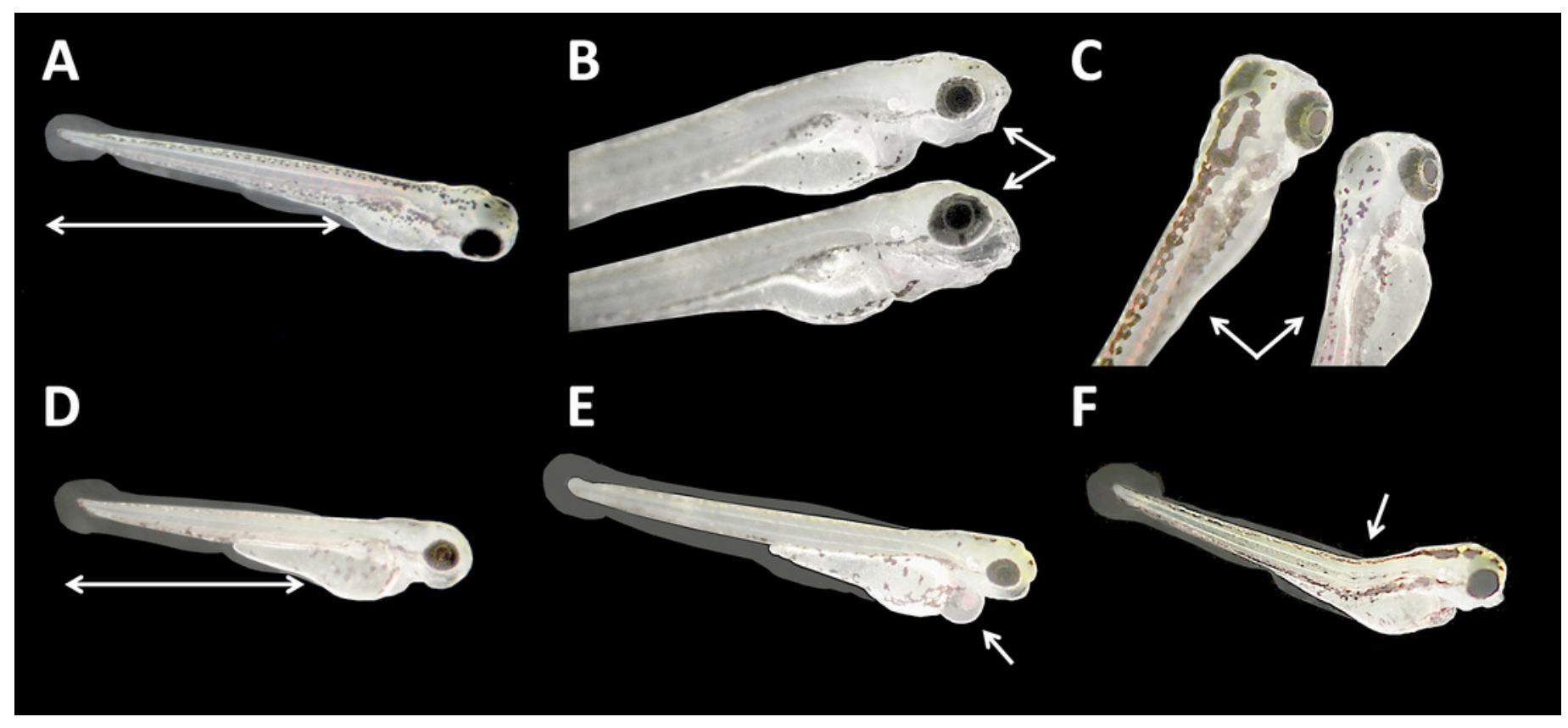




\section{Figure 5}

Figure 5: Mortality over time as percentages of embryos exposed to the $\mathrm{pH}$ control [A] and glyphosate [B].

Respective concentrations of glyphosate are given in brackets. Results from unbuffered treatments ( $50 \mu \mathrm{M}-10 \mathrm{mM}$ glyphosate; highlighted in red) are combined with $\mathrm{pH}$ range results and positioned according to their measured $\mathrm{pH}$. Treatments not conducted in the $\mathrm{pH}$ control or glyphosate scheme are labelled n.a. (not available). Significant differences from the negative control are marked with asterisks $(*)$, except glyphosate $\mathrm{pH} 3.4$ with an additional significant comparison between unbuffered and pH 7 treatment. Significances between $\mathrm{pH}$ control and glyphosate treatments within respective $\mathrm{pH}$ ranges are denoted with letters $(a, b)$ (Cox regression, $p<0.01)$. 


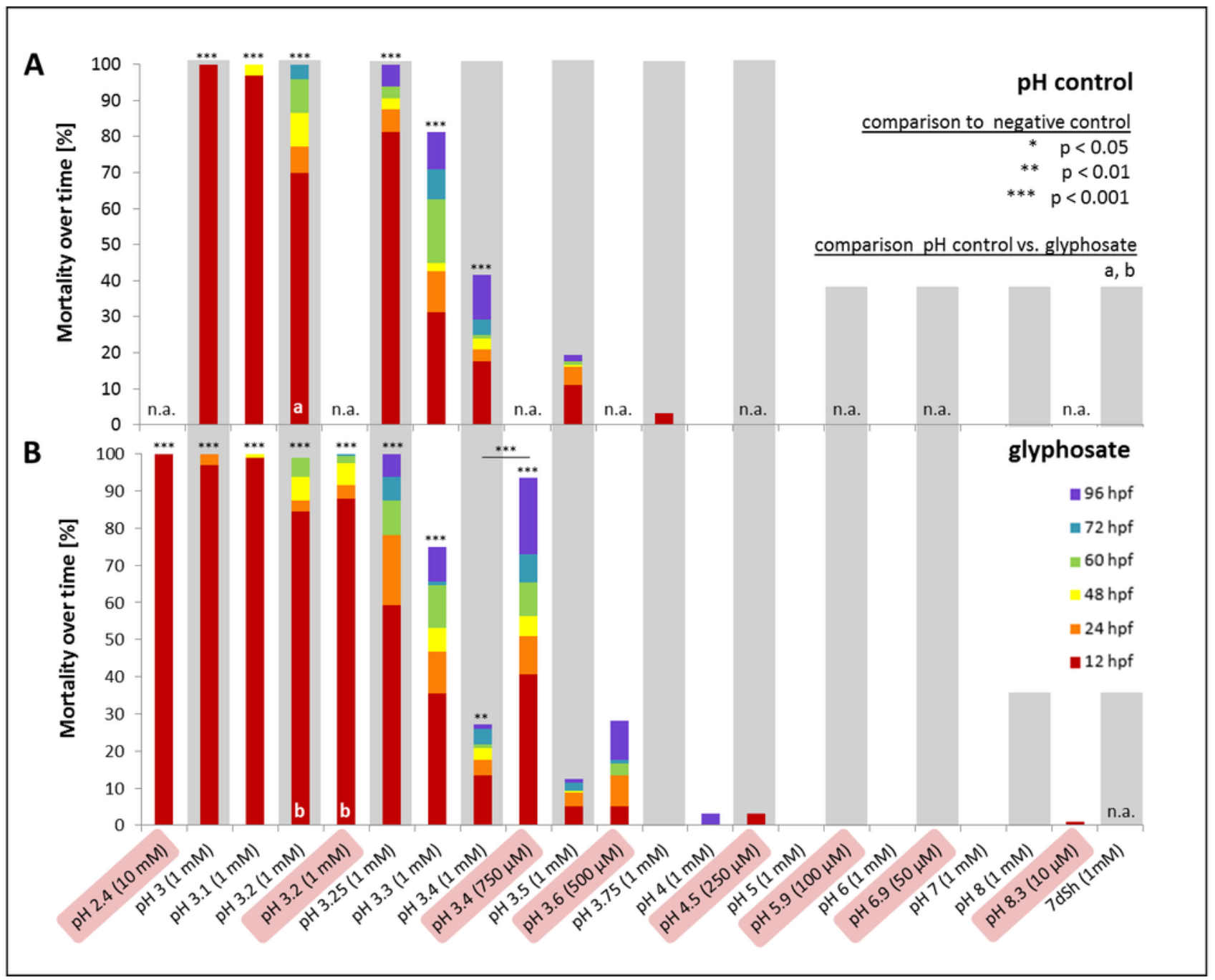


Figure 6

Figure 6: Mean deviation of the heart rate from the negative control in percent as a function dependent on $\mathrm{pH} ; \mathrm{pH}$ control: $\mathrm{y}=\mathrm{a}+\mathrm{bx}+\mathrm{cx}^{1.5}+\mathrm{dx}^{2.5}+\mathrm{ex}^{0.5}$; glyphosate: $\mathrm{y}=$ $a+b x+c x^{2}+d e^{x}+e(\ln x)[s u$

Coloured areas mark the $95 \%$ confidence interval. Green lines confine the $\mathrm{pH}$ range (between pH 5.55 and pH 6.05) in which the $95 \%$ confidence intervals of pH control and glyphosate do not overlap and thus, where heart rates differ significantly from each other.

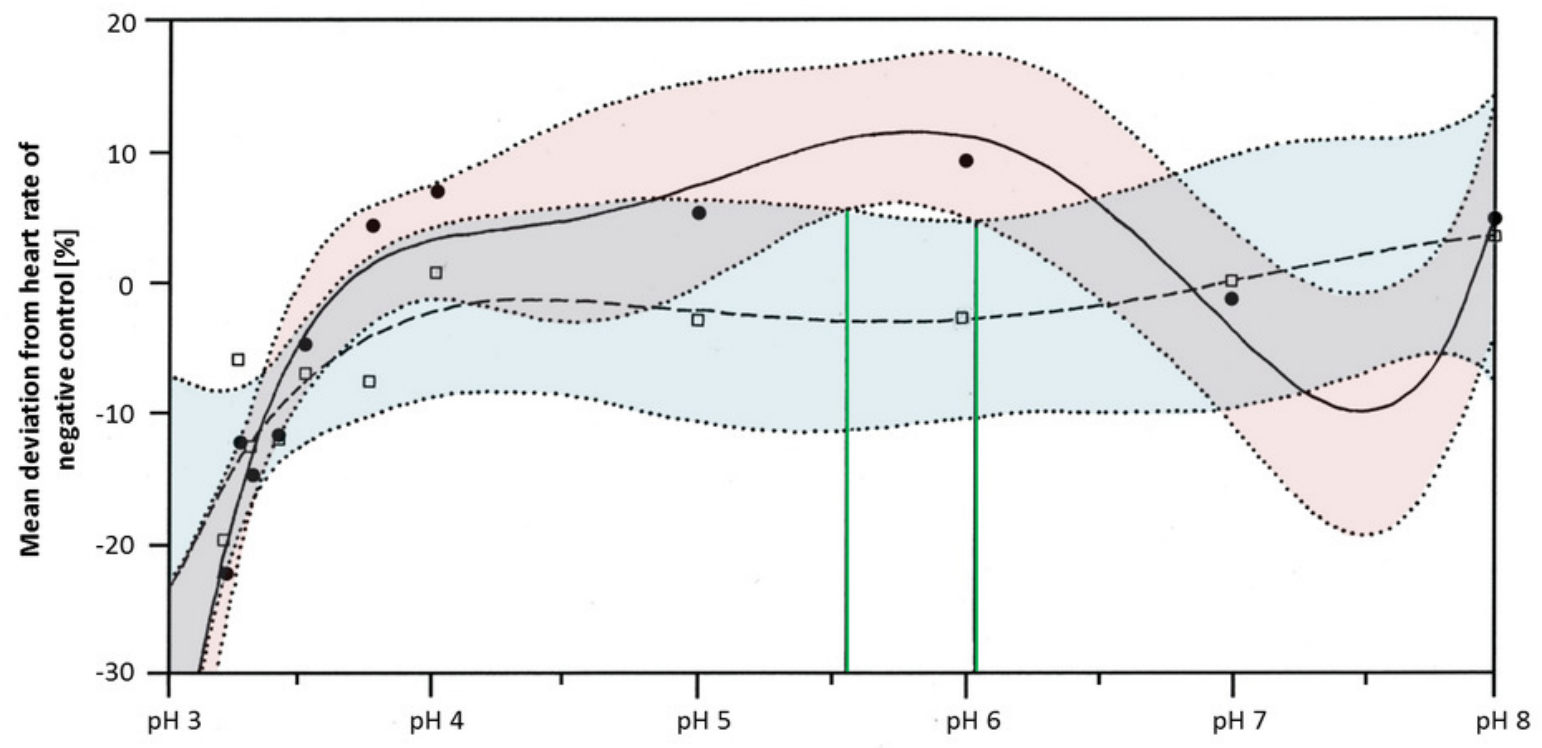




\section{Table $\mathbf{1}$ (on next page)}

Table 1: Tested glyphosate concentrations including their corresponding values in $\mathrm{mg} / \mathrm{L}$ and resulting $\mathrm{pH}$ in solution. 
1

\begin{tabular}{|ccc|}
\hline MOLARITY & $\mathrm{mg} / \mathrm{L}$ & $\mathrm{pH}$ \\
\hline $10 \mu \mathrm{M}$ & 1.69 & 8.3 \\
\hline $50 \mu \mathrm{M}$ & 8.45 & 6.9 \\
\hline $100 \mu \mathrm{M}$ & 16.91 & 5.9 \\
\hline $250 \mu \mathrm{M}$ & 42.27 & 4.5 \\
\hline $500 \mu \mathrm{M}$ & 84.54 & 3.6 \\
$750 \mu \mathrm{M}$ & 126.80 & 3.4 \\
\hline $1 \mathrm{mM}$ & 169.07 & 3.2 \\
\hline $10 \mathrm{mM}$ & 1690.7 & 2.4 \\
\hline
\end{tabular}

2

3

4 


\section{Table 2 (on next page)}

Table 2: Overview of observed lethal and sublethal endpoints at respective time points. 
1

\begin{tabular}{|c|c|c|c|c|c|c|}
\hline ENDPOINT & 12 hpf & 24 hpf & $48 \mathrm{hpf}$ & $60 \mathrm{hpf}$ & 72 hpf & 96 hpf \\
\hline Mortality & $\checkmark$ & $\checkmark$ & $\checkmark$ & $\checkmark$ & $\checkmark$ & $\checkmark$ \\
\hline Developmental delays & & $\checkmark$ & & & & \\
\hline - no somites & & $\checkmark$ & & & & \\
\hline - non-detachment of the tail & & $\checkmark$ & & & & \\
\hline - no development of the eyes & & $\checkmark$ & & & & \\
\hline Heart rate & & & $\checkmark$ & & & \\
\hline Hatching success & & & & $\checkmark$ & $\checkmark$ & $\checkmark$ \\
\hline Malformations & & & & & & $\checkmark$ \\
\hline - oedema & & & & & & $\checkmark$ \\
\hline - $\quad$ eye/brain defects & & & & & & $\checkmark$ \\
\hline - deformation of the spine & & & & & & $\checkmark$ \\
\hline - light pigmentation & & & & & & $\checkmark$ \\
\hline
\end{tabular}

2 


\section{Table 3 (on next page)}

Table 3: Results for concentration-dependent glyphosate treatments, as well as for $\mathrm{pH}$ dependent control and glyphosate treatments, as percentages.

Asterisks (*) indicate statistically significant differences from the negative control (Cox regression, ANOVA: $* p<0.05, * * p<0.01, * * * p<0.001$; Likelihood ratio $\chi^{2}$, Fisher's exact test, Bonferroni-Holm: $* p<\alpha$ ). Crosses ( $\square$ ) denote additional statistical significances between $\mathrm{pH}$ control and glyphosate within the same $\mathrm{pH}$ range or, in the case of $7 \mathrm{dSh}$, differences from $1 \mathrm{mM}$ glyphosate at pH 7. For unbuffered glyphosate concentrations, endpoint-related $\mathrm{LC}_{10} / \mathrm{EC}_{10}$ and $\mathrm{LC}_{50} / \mathrm{EC}_{50}$ values are given. $\mathrm{HR}$ - heart rate, $\mathrm{D}$ - developmental delays, $\mathrm{M}$ malformations, n.s - not significant, n.a. - not available (no sufficient sample sizes for statistical analysis). 
1

\begin{tabular}{|c|c|c|c|c|c|c|}
\multicolumn{2}{c|}{ MORTALITY } & \multicolumn{2}{c|}{ HATCHING } & HR & D & M \\
\hline $96 \mathrm{hpf}[\%]$ & over time & $96 \mathrm{hpf}[\%]$ & over time & $48 \mathrm{hpf}[\mathrm{bpm}]$ & $24 \mathrm{hpf}[\%]$ & $96 \mathrm{hpf}[\%]$ \\
\hline
\end{tabular}

UNBUFFERED

\begin{tabular}{|c|c|c|c|c|c|c|c|}
\hline Neg. control & 0 & - & 97.92 & - & 148.75 & 0 & 0.26 \\
\hline $10 \mu \mathrm{M}$ & 1.04 & n.s. & 97.92 & $*$ & $138.38 * * *$ & 0 & $2.36 *$ \\
\hline $50 \mu \mathrm{M}$ & 0 & n.s. & 98.96 & $*$ & $134.19 * * *$ & 0 & $5.47^{*}$ \\
\hline $100 \mu \mathrm{M}$ & 0 & n.s. & 100 & $* * *$ & $128.69 * * *$ & 0 & $4.69 *$ \\
\hline $250 \mu \mathrm{M}$ & 3.13 & n.s. & $40.65^{*}$ & $* * *$ & $125.56 * * *$ & $22.23^{*}$ & $13.57^{*}$ \\
\hline $500 \mu \mathrm{M}$ & $28.13^{*}$ & $*$ & $40.58 *$ & $* * *$ & $118.63 * * *$ & $20.36 *$ & $16.06^{*}$ \\
\hline $750 \mu \mathrm{M}$ & $93.64 *$ & $* * *$ & $33.33^{*}$ & n.a. & $94.50 * * *$ & $19.04 *$ & $18.06^{*}$ \\
\hline $1 \mathrm{mM}$ & $100 *$ & $* * *$ & n.a. & n.a. & n.a. & n.a. & n.a. \\
\hline $10 \mathrm{mM}$ & $100 *$ & $* * *$ & n.a. & n.a. & n.a. & n.a. & n.a. \\
\hline $\mathrm{LC}_{10} / \mathrm{EC}_{10}$ & \multicolumn{2}{|c|}{$385 \mu \mathrm{M}$} & \multicolumn{2}{|c|}{$155 \mu \mathrm{M}$} & $43 \mu \mathrm{M}$ & $126 \mu \mathrm{M}$ & $179 \mu \mathrm{M}$ \\
\hline $\mathrm{LC}_{50} / \mathrm{EC}_{50}$ & \multicolumn{2}{|c|}{$582 \mu \mathrm{M}$} & \multicolumn{2}{|c|}{$224 \mu \mathrm{M}$} & - & - & - \\
\hline
\end{tabular}

7dSh

\begin{tabular}{l|l|l|l|lll}
\hline neutral & 0 & n.s. & 98.93 & $*$ & $139.75^{* * *,(\odot)}$ & 0.35 \\
\hline
\end{tabular}

pH 7

\begin{tabular}{|c|c|c|c|c|c|c|c|}
\hline Neg. control & 0 & - & 85.42 & - & 148.04 & 0 & 0.52 \\
\hline $10 \mu \mathrm{M}$ & 1.04 & n.s. & $100 *$ & $* * *$ & 144.25 & 0 & 1.04 \\
\hline $50 \mu \mathrm{M}$ & 1.04 & n.s. & $100 *$ & $* * *$ & 142.56 & 1.04 & 1.87 \\
\hline $100 \mu \mathrm{M}$ & 0 & n.s. & 98.96* & $* * *$ & $136.57 * *$ & 0 & 2.60 \\
\hline $250 \mu \mathrm{M}$ & 0 & n.s. & $100 *$ & $* * *$ & $130.31 * * *$ & 0 & 0.26 \\
\hline $500 \mu \mathrm{M}$ & 0 & n.s. & $100 *$ & $* * *$ & $129.19 * * *$ & 0 & 1.56 \\
\hline $750 \mu \mathrm{M}$ & 1.04 & n.s. & $100 *$ & $* * *$ & $133.50 *$ & 0 & 2.35 \\
\hline $1 \mathrm{mM}$ & 0 & n.s. & 98.96* & $* * *$ & 145.94 & 0.69 & $6.56 *$ \\
\hline $10 \mathrm{mM}$ & 0 & n.s. & 94.79* & $* * *$ & 149.38 & 0 & $7.29 *$ \\
\hline
\end{tabular}

PH RANGE - CONTROL

\begin{tabular}{|c|c|c|c|c|c|c|c|}
\hline Neg. control & 0 & - & 94.69 & - & 160.38 & 0 & 0.26 \\
\hline pH 3 & $100 *$ & $* * *$ & n.a. & n.a. & n.a. & n.a. & n.a. \\
\hline pH 3.1 & $100 *$ & $* * *$ & n.a. & n.a. & n.a. & n.a. & n.a. \\
\hline pH 3.2 & $100 *$ & $* * *$ & n.a. & n.a. & n.a. & n.a. & n.a. \\
\hline pH 3.3 & 84.03* & $* * *$ & $61.11 *$ & $* * *$ & $140.19 * * *$ & 9.36* & $4.17^{*}$ \\
\hline
\end{tabular}




\begin{tabular}{|c|c|c|c|c|c|c|c|}
\hline pH 3.4 & $51.04 *$ & $* * *$ & 77.78*,@ & $* * *$ & $141.38 * * *$ & $6.93^{*}$ & $3.51^{*}$ \\
\hline pH 3.5 & $8.33^{*}$ & n.s. & $15.77^{*, \odot)}$ & $* * *$, (5) & $144.25 * * *$ & $8.32 *$ & $2.0^{*}$ \\
\hline & \multicolumn{7}{|c|}{ pH RANGE - GLYPHOSATE } \\
\hline pH 3 & $100 *$ & $* * *$ & n.a. & n.a. & n.a. & n.a. & n.a. \\
\hline pH 3.1 & $100 *$ & $* * *$ & n.a. & n.a. & n.a. & n.a. & n.a. \\
\hline pH 3.2 & $100 *$ & $* * *$ & n.a. & n.a. & n.a. & n.a. & n.a. \\
\hline pH 3.3 & $72.57 *$ & $* * *$ & 83.33 & $* * *$ & $136.46 * * *$ & $13.33^{*}$ & 0 \\
\hline pH 3.4 & $28.47^{*}$ & $* * *$ & $60.61 *,()$ & $* * *$ & $141.49 * * *$ & $4.54^{*}$ & $3.80 *$ \\
\hline pH 3.5 & $17.36 *$ & n.s. & $66.57^{*,(3)}$ & $* * *,($ () & $143.50 * * *$ & $10.31 *$ & $2.04^{*}$ \\
\hline
\end{tabular}

2 